\title{
Seasonal microbial processes in a high-latitude fjord (Kongsfjorden, Svalbard): I. Heterotrophic bacteria, picoplankton and nanoflagellates
}

\author{
Kriss Rokkan Iversen • Lena Seuthe
}

Received: 23 November 2009 / Revised: 4 November 2010 / Accepted: 8 November 2010 / Published online: 2 December 2010

(C) The Author(s) 2010. This article is published with open access at Springerlink.com

\begin{abstract}
Temporal dynamics of the microbial food web in the Barents Sea and adjacent water masses in the European Arctic are to a large extent unknown. Seasonal variation in stocks and production rates of heterotrophic bacteria and phototrophic and heterotrophic picoplankton and nanoflagellates was investigated in the upper $50 \mathrm{~m}$ of the highlatitude Kongsfjorden, Svalbard, during six field campaigns between March and December 2006. Heterotrophic bacteria, picoplankton and nanoflagellates contributed to ecosystem structure and function in all seasons. Activity within the microbial food web peaked during spring bloom in April, parallel to low abundances of mesozooplankton. In the nutrient-limited post-bloom scenario, an efficient microbial loop, fuelled by dissolved organic carbon from abundant mesozooplankton feeding on phytoplankton and protozooplankton, facilitated maximum integrated primary production rates. A tight microbial food web consisting of heterotrophic bacteria and phototrophic and heterotrophic picoplankton and nanoflagellates was found in the stratified water masses encountered in July and September. Microbial stocks and rates were low but persistent under winter conditions. Seasonal comparisons of microbial biomass and production revealed that structure and function of the microbial food web were fundamentally different during the spring bloom when compared with other seasons. While the microbial food web was in a regenerative mode most of the time, during the spring bloom, a microbial transfer
\end{abstract}

K. Rokkan Iversen $(\varangle) \cdot$ L. Seuthe

Department of Arctic and Marine Biology,

Faculty of Biosciences, Fisheries and Economics,

University of Troms $\varnothing$, Breivika, 9037 Troms $\varnothing$, Norway

e-mail: kriss.iversen@uit.no mode represented a trophic link for organic carbon in time and space. The microbial food web's ability to fill different functional roles in periods dominated by new and regenerated production may enhance the ecological flexibility of pelagic ecosystems in the present era of climate change.

Keywords Microbial food web - Seasonal - Arctic . Bacteria $\cdot$ Picoplankton $\cdot$ Nanoflagellates

\section{Introduction}

Arctic water masses are currently subjected to climateinduced alterations likely to influence marine ecosystems and biogeochemical pathways (e.g. Arctic Climate Impact Assessment 2004). Basic knowledge on structure and function of arctic ecosystems is thus crucial for predicting future changes. Seasonal variations in physical and chemical properties of arctic water masses are likely to affect and alter the marine ecosystem and its ecological impact in the same location over a year. In addition, the heterogeneous nature of high-latitude seas (Carmack and Wassmann 2008) implies that structure and function of marine ecosystems may differ between geographical areas throughout the panArctic region.

The Barents Sea and adjacent water masses in the European Arctic represent a complex combination of Atlantic and Arctic water masses (e.g. Loeng et al. 1997) under an Arctic light regime. Even though this productive and dynamic shelf-sea (e.g. Falk-Petersen et al. 2000; Wassmann 2002) is well-studied, the ecological significance of the microbial food web in the European Arctic in general is still relatively unknown. However, the literature available suggests that the microbial food web is as important in specific ecological events, such as the vernal bloom and the 
post-bloom situation, in the Arctic as reported for temperate seas (e.g. Hansen et al. 1996; Verity et al. 1999; Rat'kova and Wassmann 2002; Not et al. 2005; Hodal and Kristiansen 2008; Sturluson et al. 2008). Datasets covering several physical, chemical and biological parameters over an Arctic year in the European Arctic have, however, not earlier been generated.

The high-latitude Kongsfjorden $\left(79^{\circ} \mathrm{N}\right)$, situated at the west coast of the Svalbard Archipelago, represents a unique site for seasonal studies of the marine ecosystem in the European Arctic. This is due to the combination of infrastructure, accessibility, arctic climate and association with the Barents Sea. The marine ecosystem in Kongsfjorden is well known with regard to hydrography, mesozooplankton and higher trophic levels, while knowledge on the microbial food web is still insufficient (Hop et al. 2002). While additional investigations of microbial organisms and processes have been conducted recently (e.g. Jankowska et al. 2005; Wiktor and Wojciechowska 2005; Thingstad et al. 2008; Piwosz et al. 2009; Wang et al. 2009), comprehensive knowledge on seasonal dynamics is still missing.

The overall objective of this study was to conduct an annual sequence of studies of the microbial food web in the high-latitude Kongsfjorden, situated in the European Arctic. In order to cover both the polar night and midnight sun period, basic elements of the microbial food web and its physical and chemical environment were investigated in Kongsfjorden from March to December 2006. More specifically, we investigated (i) the significance of the microbial food web for ecosystem structure and function in Kongsfjorden during different seasons and (ii) how seasonal variations in the physical and chemical environment influenced the microbial food web with regard to different microbial organism groups and their role in carbon cycling. In this paper, we focus on heterotrophic bacteria, picoplankton and nanoflagellates, while dinoflagellates, ciliates and mesozooplankton are presented elsewhere (Seuthe et al. accepted).

\section{Method}

Study site and sampling programme

Kongsfjorden is a glacial fjord situated at the west coast of Svalbard $\left(79^{\circ} \mathrm{N}, 12^{\circ} \mathrm{E}\right.$; Fig. 1). This study was conducted at station KB3, located close to the settlement of Ny-Ålesund in Kongsfjorden (depth 300 m; Fig. 1). The station was sampled during six field campaigns in 2006 (March 18, April 25, May 30, July 4, September 16 and December 2) covering both spring, summer, autumn and winter conditions.

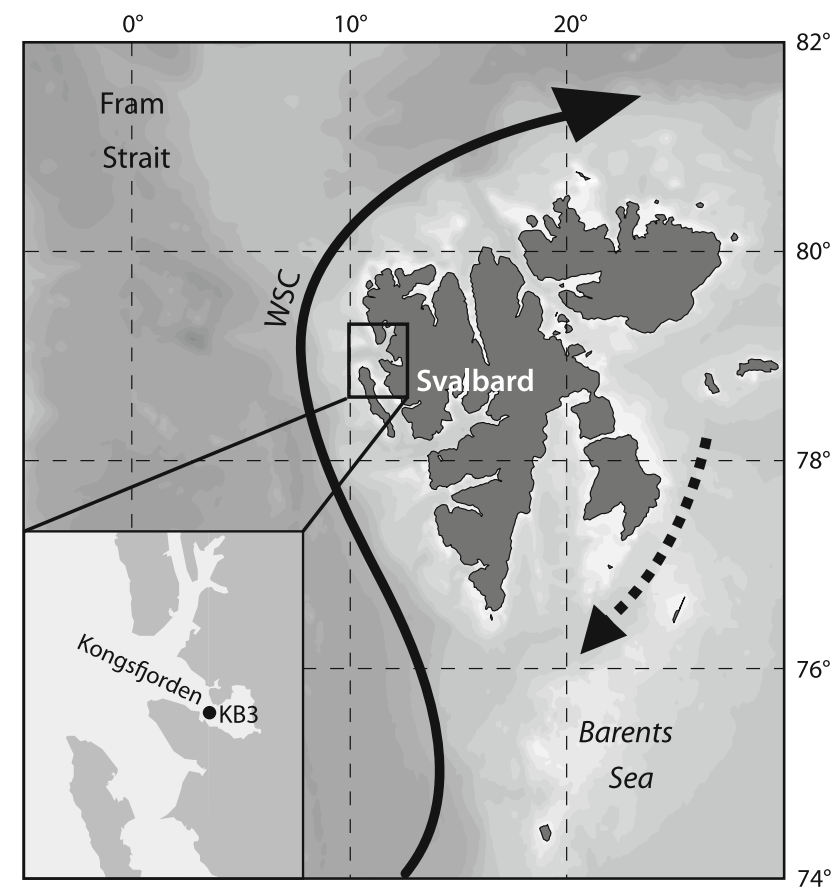

Fig. 1 Schematic overview over the main current system around the Svalbard Archipelago, with the West Spitsbergen Current (WSC) transporting warm Atlantic water along the west coast of Svalbard. The present study was conducted in Kongsfjorden (station KB3, $78^{\circ} 57^{\prime} \mathrm{N}$, $\left.11^{\circ} 56^{\prime} \mathrm{E}\right)$ at the west coast of Spitsbergen

Hydrography, nutrients, and carbon compounds

Water samples from six discrete depths were collected with $10-1$ Niskin bottles $(1,5,10,15,25$ and $50 \mathrm{~m})$. Vertical profiles of salinity and temperature $\left({ }^{\circ} \mathrm{C}\right)$ were measured with a CTD (SBE 19+). Subsamples for nutrient analyses (nitrate, nitrite, phosphate and silicate) were frozen and later analysed by standard seawater methods applying a Flow Solution IV analyzer (OI Analytical, US), calibrated with reference seawater (Ocean Scientific International Ltd., UK). Due to the small amounts of nitrite, nitrate and nitrite combined are in the following called nitrate for simplicity.

For analysis of particulate organic carbon (POC), triplicate subsamples $(100-1,500 \mathrm{ml})$ were filtered on precombusted Whatman $\mathrm{GF} / \mathrm{F}$ glass-fibre filters $\left(450^{\circ} \mathrm{C}\right.$ for $5 \mathrm{~h}$ ), dried at $60^{\circ} \mathrm{C}$ for $24 \mathrm{~h}$ and analysed on-shore with a Leeman Lab CEC $440 \mathrm{CHN}$ analyzer after removal of carbonate by fuming with concentrated $\mathrm{HCl}$ for $24 \mathrm{~h}$.

Duplicated water samples for analyses of dissolved organic carbon (DOC) were filtered on burned Whatman GF/F glass-fibre filters $(0.7-\mu \mathrm{m}$ pore size) and frozen $\left(-20^{\circ} \mathrm{C}\right)$ in $15-\mathrm{ml}$ acid-washed Nalgene vials in all months, except March. In March, samples of unfiltered profile water were frozen $\left(-20^{\circ} \mathrm{C}\right)$, and consequently, total organic carbon (TOC) was measured for this month. DOC concentrations for March were thus estimated from the TOC and 
POC concentrations. All samples were measured three times in a SHIMADZU TOC- $\mathrm{V}_{\mathrm{CPH} / \mathrm{CPN}}$ analysator.

Chlorophyll $a$ and primary production

Triplicated subsamples of profile water were filtered onto Whatman GF/F glass-fibre filters and Whatman membrane filters (pore size $10 \mu \mathrm{m}$ ) to measure total and size-fractionated $(10 \mu \mathrm{m})$ chlorophyll $a(\mathrm{chl} a)$, respectively. Filters were immediately frozen for $5-7$ days $\left(-20^{\circ} \mathrm{C}\right)$. Prior to fluorometrical analysis (Parsons et al. 1984), samples were extracted in $5 \mathrm{ml}$ methanol for $12 \mathrm{~h}$ at room temperature in the dark without grinding. The fluorescence of the extract was measured with a Turner Design Fluorometer (Model 10-AU), calibrated with pure chl $a$ (Sigma).

Primary production (PP) was measured in situ using the ${ }^{14} \mathrm{C}$ method (Parsons et al. 1984). Aliquots of profile water were collected in polycarbonate bottles $(320 \mathrm{ml})$ and labelled with $4 \mu \mathrm{Ci}$ (final concentration $0.0125 \mu \mathrm{Ci} \mathrm{ml} \mathrm{m}^{-1}$ ) ${ }^{14} \mathrm{C}$-bicarbonate, before incubation at respective depths for $24 \mathrm{~h}$. After incubation, samples were filtered onto Whatman $\mathrm{GF} / \mathrm{F}$ glass-fibre filters and frozen $\left(-20^{\circ} \mathrm{C}\right)$ immediately after filtration. The samples were counted in a liquid scintillation analyzer with quench correction (PerkinElmer TriCarb 2900TR), after fuming with $\mathrm{HCl}$ and adding $10 \mathrm{ml}$ of Ultima Gold ${ }^{\mathrm{TM}}$ XP (Packard). For production rate calculations, total $\mathrm{CO}_{2}$ was assumed to be $2.05 \mathrm{mM}$ (Gargas 1975).

Phytoplankton and protozooplankton

Aliquots of profile water $(500 \mathrm{ml})$ were preserved with acid Lugol (2\% final concentration) for taxonomic and quantitative analyses of dinoflagellates, ciliates and diatoms. Samples were stored dark and cool $\left(+4^{\circ} \mathrm{C}\right)$ until analysis. Subsamples were analysed at a magnification of $\times 200$ and $\times 400$ (inverted microscope, Nikon TE 200), after settling in Utermöhl sedimentation chambers.

Quantitative analyses of picoplankton and nanoflagellates, as well as analysis of trophic modes (photo- and heterotrophic), were performed on subsamples fixed with glutaraldehyde (final concentration 1\%), filtered onto $0.8-\mu \mathrm{m}$ black polycarbonate filters and stained with DAPI (Porter and Feig 1980) at $5 \mu \mathrm{g}^{-1}$. The filters were mounted on slides and frozen at $-20^{\circ} \mathrm{C}$ to preserve the chlorophyll autofluorescence (Porter and Feig 1980; Bloem et al. 1986; Sanders et al. 1989), before being counted with a Leica DM LB2 epifluorescence microscope under blue (filter D; 355$425 \mathrm{~nm}$ ) and green (filter N2.1; 515-560 nm) excitation at $\times 1,000$ magnification. Cells containing chloroplasts were regarded as phototrophs, although this group can also include mixotrophs. We operated with the following functional groups: picoplankton $(0.2-2 \mu \mathrm{m})$ and nanoflagellates $(2-20 \mu \mathrm{m})$. For nanoflagellates, we further divided the functional group into the following size classes of flagellates: (a) 2-5 $\mu \mathrm{m}$, (b) 5-10 $\mu \mathrm{m}$ and (c) 10-20 $\mu \mathrm{m}$. The latter deviation was done to increase the resolution in the estimation of biomass and related estimates.

Quantitative analyses of other phytoplankton groups and taxonomic analyses of all phytoplankton groups were performed on Primulin-stained samples according to methods described in Rat'kova and Wassmann (2002). Many algae could be identified to genus or to higher taxa only.

The biovolume of algae and protozoan cells was calculated from the volumes of appropriate stereometrical bodies (Smayda 1978). The carbon content of phytoplankton and dinoflagellate cells was estimated according to MendenDeuer and Lessard (2000). For aloricate and loricate ciliates, the biomass was estimated using a volume to carbon conver-

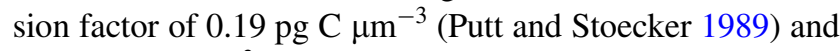
0.053 pg C $\mu^{-3}$ (Verity and Langdon 1984), respectively. For picoplankton $(0.2-2 \mu \mathrm{m})$ and the three size classes of nanoflagellates, the median in each size spectrum was applied when estimating bulk carbon biomass.

Heterotrophic bacteria and bacterial production

Abundance of heterotrophic bacteria was determined by flowcytometry. All analyses were performed with a FACSCalibur flow cytometer (Becton-Dickinson) equipped with standard filter set-up and with an air-cooled laser, providing $15 \mathrm{~mW}$ at $488 \mathrm{~nm}$. Enumeration of bacteria was performed on samples fixed with glutaraldehyde for $60 \mathrm{~s}$ at an event rate between 100 and $1,000 \mathrm{~s}^{-1}$. Each sample was diluted 50- to 500-fold before it was stained with SYBR Green I. Flow cytometer instrumentation and the remaining methodology followed the recommendations of Marie et al. (1999). For more details, see Larsen et al. (2001). Bacterial carbon biomass was estimated by assuming a carbon content of $12.4 \mathrm{f} \mathrm{g} \mathrm{C} \mathrm{per} \mathrm{bacteria} \mathrm{(Fukuda} \mathrm{et} \mathrm{al.} \mathrm{1998).}$

Bacterial production (BP) was measured by incorporation of tritiated leucine (60- and 70-nM final concentrations) in bacterial protein synthesis (Kirchman et al. 1985), as modified by Smith and Azam (1992). The samples were incubated in dark conditions at in situ temperatures for $60 \mathrm{~min}$, before the production was stopped by adding $100 \%$ trichloricaceticacid (TCA). Samples were stored at $+4^{\circ} \mathrm{C}$ prior to counting in a liquid scintillation analyzer with quench correction (PerkinElmer Tri-Carb 2900TR). The bacterial uptake of leucine was converted to bacterial carbon production (Simon and Azam1989) applying a leucine conversion factor of 1.5, assuming no isotope dilution.

\section{Data analysis}

The multidimensional nature of the collected data, with several response variables (bacterial abundance, bacterial 
production rates, abundance of picoplankton, nanoflagellates and diatoms) being measured for the phototrophic and heterotrophic components of the microbial food web in six field campaigns, prompted the application of multivariate analysis. Multivariate ordination methods are an efficient tool for the analysis of ecological gradients (Legendre and Legendre 1998), exploiting the correlations between response variables, a valuable feature for the present study that aimed at an integrated analysis of the response of the microbial food web to seasonal variations of physical (temperature, salinity), chemical (inorganic nutrients) and biological (predators) properties in the water masses. Ordination methods (Legendre and Legendre 1998) were used to describe the variation in response variables (Principal Component Analysis, PCA) and model their relationship with the environmental factors (Redundancy Analysis, RDA). RDA allows partitioning of the influence of different environmental factors on the total variation in the response of the microbial food web (Legendre and Legendre 1998). Several models specifying alternative relations between response variables and environmental factors were estimated using the statistical software $\mathrm{R}$ and their performance was compared. Model selection based on goodness of fit criteria (selecting model accounting for highest variation in response variables) allowed us to assess the structure of the relationships between microbial response variables and environmental factors. The response variables were $\log$ transformed and standardized to facilitate comparison and to meet the underlying assumptions of RDA. Model results were reproduced in ordination biplots summarizing the main trends in the data. The biplot displays response and explanatory variables as vectors (arrows point in the direction of increasing variable values) in a reduced ordination space (e.g. two dimensions). Correlations between variables are shown by the angle between arrows (an angle $<90^{\circ}$ between two arrows of interest implies positive correlation), whereas the length of an arrow depicts the strength of association between a variable and the ordination axes shown in the biplot. Models were tested by permutation (Monte Carlo test, with 500 permutations) (Legendre and Legendre 1998), to check whether the response variables were significantly correlated with the environmental factors.

\section{Results}

\section{Hydrography}

Kongsfjorden was dominated by an inflow of Atlantic water in January/February 2006 (Cottier et al. 2007). Extensive cooling and strong winds led to a thoroughly mixed water column in March, with temperatures of $0.6 \pm 0.1^{\circ} \mathrm{C}$ and salinity of $34.7 \pm 0.2$ (Fig. 2). A weak pycnocline was observed at approximately $30 \mathrm{~m}$ in April, even though temperatures still remained low $\left(0.6 \pm 0.1^{\circ} \mathrm{C}\right)$. Density gradients were influenced by warmer temperatures and/or freshwater discharge from May $\left(2^{\circ} \mathrm{C}\right)$ and onwards in July and September $\left(3-6^{\circ} \mathrm{C}\right)$. In summer and autumn, freshwater runoff from land and glaciers generated strong salinity gradients, with surface water salinity of $33.8 \pm 0.9$ (July/September, Fig. 2), which led to stratification at shallow depths in July (pycnocline at approximately $10 \mathrm{~m}$ ) and September (pycnocline at approximately $30 \mathrm{~m}$ ). The combination of Atlantic water inflow (F. Cottier, personal

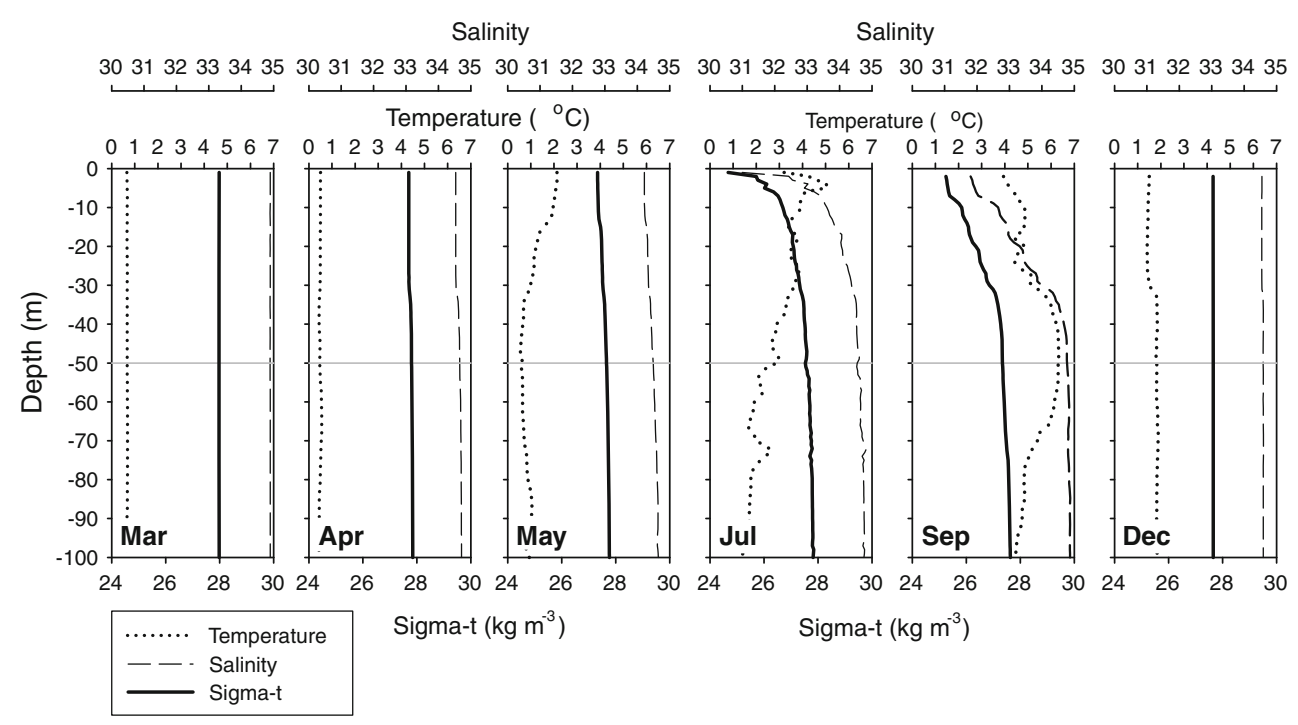

Fig. 2 Hydrographical profiles of temperature $\left({ }^{\circ} \mathrm{C}\right.$; stippled line $)$, salinity (broken line) and density $\left(\mathrm{kg} \mathrm{m}^{-3}\right.$; solid line) of the upper $100 \mathrm{~m}$ of the water column at station KB3 for the different months of sampling in 2006. The horizontal line indicates the depth of the biological sampling programme 
communication) and local freshwater runoff caused complex hydrographic features in July and September, where "fingers" of Atlantic water could be detected at various depths in the water column. In December, the water column was again well mixed, with relatively low temperatures $\left(1.5^{\circ} \mathrm{C}\right)$ and increased salinity when compared with September $(34.6 \pm 0.02)$.

Inorganic nutrients, dissolved and particulate organic carbon and chlorophyll $a$

Maximum average concentrations $(0-50 \mathrm{~m})$ of nitrate, phosphate and silicate were measured in March (Table 1). Concentrations of nitrate and phosphate decreased substantially under the phytoplankton bloom in April, and minimum concentrations were encountered in July. Both nutrients were replenished in December. The highest nitrate-to-phosphate ratios $(\mathrm{N}: \mathrm{P})$ were encountered in March and December. During the spring bloom in April, the $\mathrm{N}: \mathrm{P}$ ratio was only $25 \%$ of the initial ratio. The lowest $\mathrm{N}: \mathrm{P}$ ratios were found in May and July.

The average silicate concentration was reduced from March to April and further to May (Table 1). As for nitrate and phosphate, the average concentration of silicate also increased in September and December.

Average concentrations of DOC displayed an increase in April compared with March (Table 1) and remained stable thereafter.

Maximum average concentration of POC was encountered in April, during the vernal bloom (Table 1). After the bloom situation, the level of POC decreased gradually in the months to follow. The lowest POC concentrations were found in March and December. Based on the relationship between POC and particulate organic nitrogen (PON; data not shown), the carbon-to-nitrogen ratio $(\mathrm{C}: \mathrm{N})$ was estimated (Table 1). C:N ratios $>6.5$ were observed in March, September and December, while levels dropped under 5.5 in April, May and July.

Table 1 Average ( \pm standard deviation) concentration of nitrate, phosphate and silicate (all in $\mu \mathrm{M}$ ), as well as of dissolved organic carbon (DOC, $\mu \mathrm{g}^{-1}$ ), particulate organic carbon (POC, $\mu \mathrm{g}^{-1}$ ) and total chlorophyll $a\left(\mathrm{chl} a, \mu \mathrm{g} 1^{-1}\right)$ in the upper $50 \mathrm{~m}$ of Kongsfjorden during sampling in March, April, May, July, September and December 2006.
Maximum chl $a$ biomass was encountered during the phytoplankton bloom in April (Table 1). Smaller peaks of chl $a$ biomass were found in July and September. Cells $<10 \mu \mathrm{m}$ dominated (>60\%) the total chl $a$ biomass at all sampling days, except in April ( $>30 \%)$.

Phototrophic and heterotrophic contribution to integrated plankton abundances

Maximum integrated abundance of total phototrophic plankton was observed in July (Table 2). High integrated abundances were also encountered during the phytoplankton bloom in April (40\% of maximum) and in September (20\% of maximum). The relative numerical contribution of phototrophic plankton $<20 \mu \mathrm{m}$ to total phototrophic abundance exceeded 85\% in April, July and September. Phototrophic picoplankton $(<2 \mu \mathrm{m})$ contributed substantially to total phototrophic plankton abundances in summer and fall, particularly in July ( $>95 \%)$. Highest integrated abundances of phototrophic nanoflagellates in the size classes $2-5 \mu \mathrm{m}$ and $5-10 \mu \mathrm{m}$ were observed during the phytoplankton bloom in April. The largest phototrophic nanoflagellates $(10-20 \mu \mathrm{m})$ displayed low integrated abundances. The highest abundance for this size class was found in July.

Maximum integrated abundance of total heterotrophic plankton was observed in July, while high abundances also were observed in April and September (20\% of maximum; Table 2). Maximum integrated abundance of heterotrophic plankton $<20 \mu \mathrm{m}$ was found in July, contributing $>95 \%$ of total heterotrophic plankton (Table 2). In April and September, the abundance of heterotrophic plankton $<20 \mu \mathrm{m}$ was approximately $20 \%$ of the peak abundance. The highest integrated abundances of heterotrophic picoplankton $(<2 \mu \mathrm{m})$ were encountered in July and September. Heterotrophic nanoflagellates in the size class $2-5 \mu \mathrm{m}$ were numerically dominant in all seasons. Highest integrated abundance of larger heterotrophic nanoflagellates $(5-20 \mu \mathrm{m})$ was observed in July.

$\mathrm{N}: \mathrm{P}$ ratio is based on nitrate and phosphate concentrations in $\mu \mathrm{M}$, while the $\mathrm{C}: \mathrm{N}$ ratio is based on the relationship between POC and particulate organic nitrogen (PON; data not shown), both in $\mu \mathrm{g} 1^{-1}$. The relative contribution of $\operatorname{chl} a<10 \mu \mathrm{m}$ to total $\operatorname{chl} a$ is estimated from total chl $a$ and chl $a>10 \mu \mathrm{m}$

\begin{tabular}{llllllllll}
\hline & Nitrate & Phosphate & N:P & Silicate & DOC & POC & C:N & Total chl $a$ & $\%$ chl $a<10 \mu \mathrm{m}$ \\
\hline Mar & $9.2 \pm 0.56$ & $0.67 \pm 0.01$ & 13.5 & $5.17 \pm 0.12$ & $1,453 \pm 183^{\mathrm{a}}$ & $74 \pm 28$ & 9.4 & $0.02 \pm 0.0$ & 60 \\
Apr & $0.69 \pm 0.41$ & $0.23 \pm 0.04$ & 3.2 & $3.39 \pm 0.25$ & $2,285 \pm 108$ & $667 \pm 54$ & 5.3 & $9.87 \pm 0.82$ & 30 \\
May & $0.45 \pm 0.51$ & $0.30 \pm 0.10$ & 1.7 & $1.47 \pm 0.13$ & $2,376 \pm 556$ & $314 \pm 46$ & 4.6 & $0.18 \pm 0.01$ & 75 \\
Jul & $0.03 \pm 0.06$ & $0.12 \pm 0.03$ & 0.3 & $1.56 \pm 0.19$ & $2,233 \pm 107$ & $277 \pm 61$ & 5.1 & $1.02 \pm 0.50$ & 95 \\
Sep & $1.17 \pm 1.20$ & $0.20 \pm 0.13$ & 6.2 & $2.03 \pm 0.67$ & $1,956 \pm 291$ & $114 \pm 26$ & 7.1 & $0.52 \pm 0.20$ & 85 \\
Dec & $7.6 \pm 0.30$ & $0.55 \pm 0.04$ & 13.2 & $4.75 \pm 0.18$ & $2,282 \pm 406$ & $43 \pm 5$ & 6.6 & $0.01 \pm 0.01$ & 85 \\
\hline
\end{tabular}

a Concentration of dissolved organic carbon (DOC) in March is estimated from total organic carbon (TOC) and particulate organic carbon (POC) 
Table 2 Integrated $(0-50 \mathrm{~m})$ abundance of heterotrophic bacteria $\left(10^{12}\right.$ cells $\left.\mathrm{m}^{-2}\right)$ and total phototrophic and heterotrophic plankton $\left(10^{9}\right.$ cells $\left.\mathrm{m}^{-2}\right)$ in the upper $50 \mathrm{~m}$ of Kongsfjorden during sampling in March, April, May, July, September and December 2006. Specific size classes of phototrophic $(\mathrm{P})$ and heterotrophic $(\mathrm{H})$ plankton $<20 \mu \mathrm{m}$ are given as Pico $<2 \mu \mathrm{m}$, NAN $2-5 \mu \mathrm{m}$, NAN 5-10 $\mu \mathrm{m}$ and NAN 10-20 $\mu \mathrm{m}$, respectively. Total phototrophic and heterotrophic plankton includes all size classes and taxonomic groups. Total heterotrophic plankton includes heterotrophic picoplankton, nanoflagellates and dinoflagellates, as well as mixotrophic and heterotrophic ciliates. Abundance of diatoms and phototrophic and heterotrophic dinoflagellates and ciliates according to Seuthe et al. (accepted)

\begin{tabular}{|c|c|c|c|c|c|c|}
\hline & Mar & Apr & May & Jul & Sep & Dec \\
\hline Total phototrophic plankton ${ }^{\mathrm{a}}$ & 5 & 515 & 30 & 1,300 & 230 & 2 \\
\hline PPico $<2 \mu \mathrm{m}$ & 1.2 & 7.1 & 15.9 & 1,249 & 205.2 & 0.2 \\
\hline PNAN $2-5 \mu \mathrm{m}$ & 1.7 & 36.7 & 10.3 & 23.9 & 14.0 & 0.4 \\
\hline PNAN 5-10 $\mu \mathrm{m}$ & 0.1 & 420.4 & 1.5 & 11.8 & 1.2 & 0.0 \\
\hline PNAN 10-20 $\mu \mathrm{m}$ & 0.0 & 0.1 & 0.1 & 0.6 & 0.1 & 0.0 \\
\hline Total heterotrophic plankton ${ }^{\mathrm{b}}$ & 2 & 10 & 2 & 50 & 10 & 5 \\
\hline HPico $<2 \mu \mathrm{m}$ & 0.8 & 0.4 & 0.9 & 16.0 & 2.7 & 1.5 \\
\hline HNAN $2-5 \mu \mathrm{m}$ & 1.1 & 8.3 & 0.8 & 25.3 & 7.3 & 2.5 \\
\hline HNAN 5-10 $\mu \mathrm{m}$ & 0.0 & 1.2 & 0.2 & 7.0 & 1.0 & 0.4 \\
\hline HNAN 10-20 $\mu \mathrm{m}$ & 0.0 & 0.0 & 0.0 & 0.9 & 0.0 & 0.0 \\
\hline Heterotrophic bacteria & 10 & 30 & 218 & 164 & 45 & 14 \\
\hline
\end{tabular}

According to integrated abundances, heterotrophic bacteria were numerous in Kongsfjorden through all seasons (Table 2). Maximum abundances were observed in May and July, while the lowest abundances were encountered under winter conditions. In April and September, the integrated bacterial abundances were $15-20 \%$ of the maximum abundance in May.

Integrated biomass of phototrophic and heterotrophic plankton $<20 \mu \mathrm{m}$

Total integrated biomass of phototrophic plankton $<20 \mu \mathrm{m}$ was at its maximum in April during the phytoplankton bloom $\left(14,600 \mathrm{mg} \mathrm{C} \mathrm{m}^{-2}\right)$, while the highest integrated biomass of total heterotrophic plankton $<20 \mu \mathrm{m}$ was observed in July (560 $\mathrm{mg} \mathrm{C} \mathrm{m}^{-2}$; Fig. 3).

Maximum integrated biomass of both phototrophic (190 $\left.\mathrm{mg} \mathrm{C} \mathrm{m}^{-2}\right)$ and heterotrophic $\left(2.5 \mathrm{mg} \mathrm{C} \mathrm{m}^{-2}\right)$ picoplankton $(<2 \mu \mathrm{m})$ was observed in July. In addition, both phototrophic and heterotrophic picoplankton displayed smaller peaks in integrated biomass in September with 30 and $0.5 \mathrm{mg} \mathrm{C} \mathrm{m}^{-2}$, respectively.

Integrated biomass of phototrophic nanoflagellates in the size class $2-5 \mu \mathrm{m}$ was at its maximum in April $(150 \mathrm{mg} \mathrm{C}$ $\mathrm{m}^{-2}$ ), while integrated biomass of small heterotrophic nanoflagellates peaked in July (100 $\left.\mathrm{mg} \mathrm{C} \mathrm{m}^{-2}\right)$. Taxonomic analyses confirmed that phototrophic (e.g. Phaeocystis pouchetii), heterotrophic (e.g. Bicosta spinifera) and potentially mixotrophic (e.g. Isoselmis obonica) species were present in the 2- to 5- $\mu \mathrm{m}$ size class (Table 3).

The same biomass pattern was found in phototrophic and heterotrophic nanoflagellates in the size class $5-10 \mu \mathrm{m}$, with maximum integrated biomass of the phototrophic group observed in April $\left(14,450 \mathrm{mg} \mathrm{C} \mathrm{m}^{-2}\right)$ and the heterotrophic group in July ( $240 \mathrm{mg} \mathrm{C} \mathrm{m}^{-2}$ ). According to taxonomic information, phototrophic (e.g. Pachysphaera marshalliae), heterotrophic (e.g. Telonema subtilis) and potential mixotrophic (e.g. Dinobryon balticum) species were represented in this size class (Table 3 ).

The larger phototrophic nanoflagellates $(10-20 \mu \mathrm{m})$ showed an increase in integrated biomass from March onwards to a maximum biomass in July $\left(140 \mathrm{mg} \mathrm{C} \mathrm{m}^{-2}\right)$. Simultaneously, the integrated biomass of larger heterotrophic nanoflagellates peaked in July $\left(210 \mathrm{mg} \mathrm{C} \mathrm{m}^{-2}\right)$. As seen for the other size classes of nanoflagellates, the taxonomic analyses suggested that both phototrophic (e.g. Eutreptia eupharyngea), heterotrophic (e.g. Leucocryptos marina) and potential mixotrophic (e.g. Teleaulax acuta) species were present in the largest size class (Table 3).

Relative contribution of the microbial food web to total particulate organic carbon

In April, nanoflagellates contributed with $45 \%$ of total POC (Table 4). In May, heterotrophic bacteria accounted for $17 \%$ of total POC, while the other microbial biomass contributed with $2.5 \%$. Heterotrophic bacteria contributed at the same level also in July, whereas picoplankton, nanoflagellates and dinoflagellates constituted additional $13.5 \%$. In September, heterotrophic bacteria and the compiled biomass of the other microbial organism groups contributed with $10 \%$ of total POC each. In March and December, picoplankton, nanoflagellates, dinoflagellates and ciliates together contributed more to total POC than heterotrophic bacteria did.

Calculating the relative contribution of total phototrophic biomass (PPC) to total POC showed that PPC accounted for $65 \%$ of POC in April (Table 5), while PPC contributed only 15 and 5\% of POC in July and September, respectively. In April, nanoflagellates contributed with $70 \%$ of total PPC, while picoplankton and nanoflagellates accounted for 10 and $35 \%$, respectively, in July and September.

Integrated biomass and specific growth rates for total phototrophic plankton and heterotrophic bacteria

Maximum integrated biomass of total phototrophic plankton was observed in April (21,500 mg C m${ }^{-2}$; Fig. 4). In addition, a smaller peak was found in July $\left(1,850 \mathrm{mg} \mathrm{C} \mathrm{m}^{-2}\right)$. Specific growth rates for phototrophic plankton were $<0.1 \mathrm{~d}^{-1}$ in March, April and July, and $0.3 \mathrm{~d}^{-1}$ in September. In May, a specific growth rate of $1.2 \mathrm{~d}^{-1}$ was estimated. 

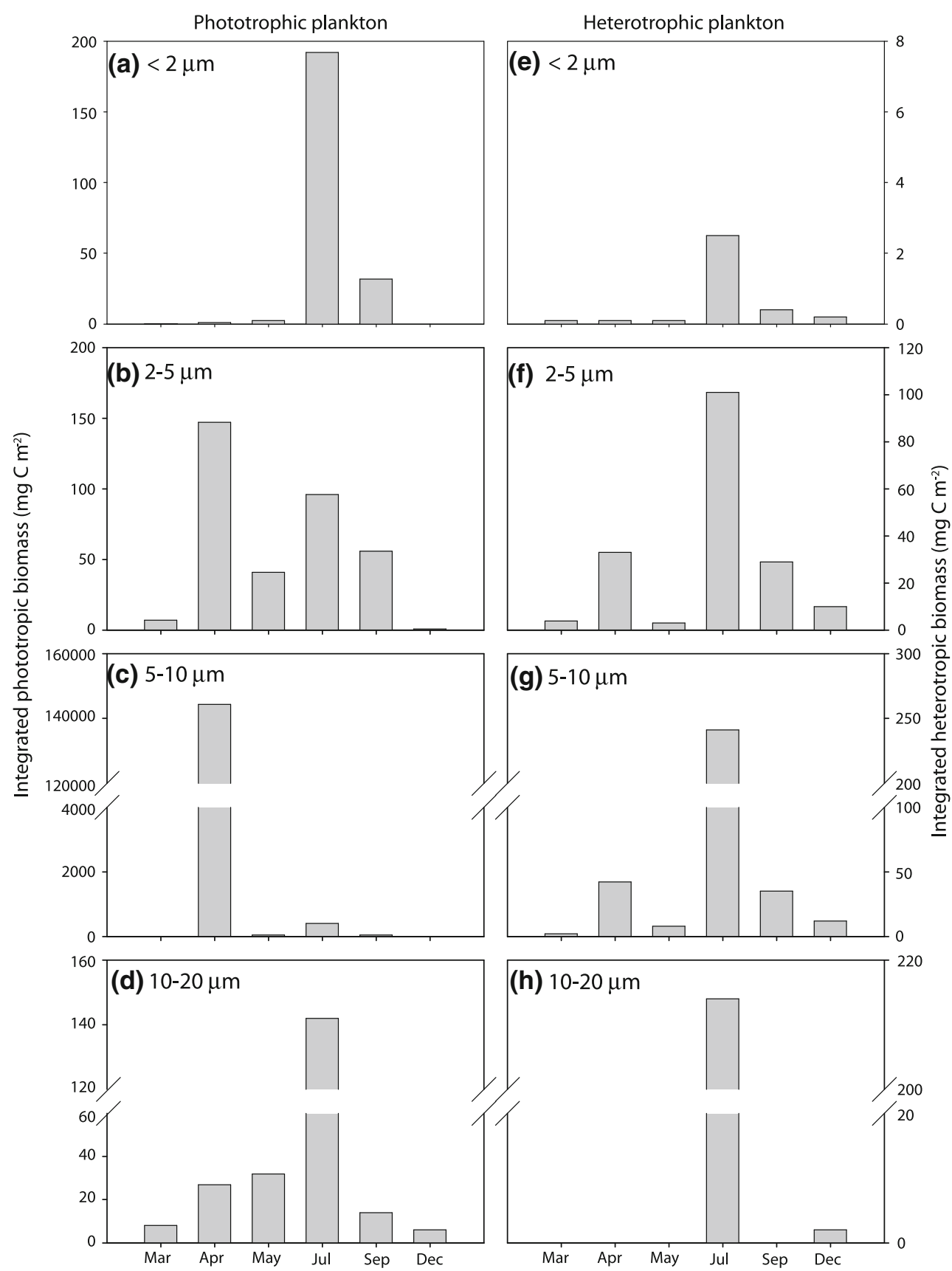

Fig. 3 Integrated biomass $\left(\mathrm{mg} \mathrm{C} \mathrm{m}^{-2}\right)$ of phototrophic and heterotrophic plankton (vertical bars) in the size classes $<2 \mu \mathrm{m}(\mathbf{a}, \mathbf{e}), 2-5 \mu \mathrm{m}$ $(\mathbf{b}, \mathbf{f}), 5-10 \mu \mathrm{m}(\mathbf{c}, \mathbf{g})$ and $10-20 \mu \mathrm{m}(\mathbf{d}, \mathbf{h})$ in the upper $50 \mathrm{~m}$ of

Kongsfjorden during sampling in March, April, May, July, September and December 2006. Note the different scales

Integrated biomass of heterotrophic bacteria was $<400 \mathrm{mg} \mathrm{C} \mathrm{m}^{-2}$ in March, April and December (Fig. 4). In May, a maximum integrated biomass of $2,700 \mathrm{mg} \mathrm{C} \mathrm{m}^{-2}$ was observed, while the integrated biomass gradually decreased in July $\left(2,000 \mathrm{mg} \mathrm{C} \mathrm{m}{ }^{-2}\right)$ and September (550 $\mathrm{mg} \mathrm{C} \mathrm{m}^{-2}$ ). Specific growth rates of heterotrophic bacteria were $<0.1$ in May, July, September and December (Fig. 4). In March, a specific growth rate of 0.2 was estimated, while a maximum specific growth rate of 4.5 was encountered in April.

Integrated $\mathrm{PP}, \mathrm{BP}$ and the $\mathrm{BP}: \mathrm{PP}$ ratio

Integrated PP was low in March (4 $\mathrm{mg} \mathrm{C} \mathrm{m}^{-2} \mathrm{~d}^{-1}$; Fig. 5). Highest integrated PP was observed in April (405 mg C $\mathrm{m}^{-2} \mathrm{~d}^{-1}$ ) and May (445 $\mathrm{mg} \mathrm{C} \mathrm{m}^{-2} \mathrm{~d}^{-1}$ ), decreasing to 155 
Table 3 List over taxonomic groups represented in different size fractions (2-5, 5-10 and 10-20 $\mu \mathrm{m})$ of nanoflagellates and potential trophic modes present according to current literature (Thomas, 1997). Phototrophic (P), heterotrophic (H) and mixotrophic (M)

\begin{tabular}{|c|c|c|c|}
\hline Taxonomic and trophic information & $2-5 \mu \mathrm{m}$ & $5-10 \mu \mathrm{m}$ & $10-20 \mu \mathrm{m}$ \\
\hline \multicolumn{4}{|l|}{ Division Chromophyta } \\
\hline $\begin{array}{l}\text { Class Prymnesiophyceae } \\
: \mathrm{P} / \mathrm{H} / \mathrm{M}\end{array}$ & $\begin{array}{l}\text { Phaeocystis pouchetii } \\
\text { : single cells } \\
: \text { cells in colonies }\end{array}$ & $\begin{array}{l}\text { Phaeocystis pouchetii } \\
: \text { single cells } \\
: \text { cells in colonies }\end{array}$ & $\begin{array}{l}\text { Phaeocystis pouchetii } \\
\text { : decaying cells }\end{array}$ \\
\hline $\begin{array}{l}\text { Class Crysophyceae } \\
: \mathrm{P} / \mathrm{H} / \mathrm{M}\end{array}$ & Calycomonas ovalis ${ }^{\mathrm{a}}$ & $\begin{array}{l}\text { Bicosaeca gracilipes }^{\mathrm{a}} \\
\text { Dinobryon balticum } \\
\text { D. faculiferum } \\
\text { Ochromonas crenata } \\
\text { O. marina } \\
\text { Pseudokephyrion } \mathrm{sp} \text {. } \\
\text { Sarcinochrysis } \mathrm{sp} .\end{array}$ & \\
\hline \multirow{3}{*}{$\begin{array}{l}\text { Class Cryptophyceae } \\
: \mathrm{P} / \mathrm{H} / \mathrm{M}\end{array}$} & Hemiselmis rufescens & & Leucocryptos marina ${ }^{\mathrm{a}, \mathrm{b}}$ \\
\hline & $\begin{array}{l}\text { Hemiselmis sp. } \\
\text { Hilea fusiformis } \\
\text { H. marina } \\
\text { Isoselmis obonica }^{\mathrm{b}}\end{array}$ & & $\begin{array}{l}\text { Plagioselmis sp. } \\
\text { Rhodomonas marina }^{\mathrm{b}} \\
\text { Teleaulax acuta }^{\mathrm{b}}\end{array}$ \\
\hline & & & Fibrocapsa japonica $^{\mathrm{c}}$ \\
\hline \multirow{3}{*}{$\begin{array}{l}\text { Class Rhaphidophyceae } \\
\text { : P }\end{array}$} & & Heterosigma sp. & Heterosigma sp. \\
\hline & & Olistodiscus luteus & \\
\hline & & & Eutreptia eupharyngea $^{\mathrm{d}}$ \\
\hline \multicolumn{2}{|l|}{ Division Chlorophyta } & & E. braarudi ${ }^{\mathrm{d}}$ \\
\hline \multicolumn{2}{|l|}{ Class Euglenophyceae } & & E. gymnastica ${ }^{\mathrm{d}}$ \\
\hline$: \mathrm{P}$ & & & $\begin{array}{l}\text { E. lanowii }^{\mathrm{d}} \\
\text { Euglena acusformis }^{\mathrm{d}} \\
\text { Euglena } \text { spp. }\end{array}$ \\
\hline \multirow{2}{*}{$\begin{array}{l}\text { Class Prasinophyceae } \\
: \mathrm{P}\end{array}$} & Pyramimonas orientalis & Pachysphaera marshalliae & Halosphaera viridis \\
\hline & $\begin{array}{l}\text { Pyramimonas sp. } \\
\text { Nephroselmis sp. }\end{array}$ & $\begin{array}{l}\text { Pyramimonas grossi }{ }^{\mathrm{b}} \\
\text { P. orientalis }\end{array}$ & $\begin{array}{l}\text { Pyramimonas octopus } \\
\text { P. orientalis }\end{array}$ \\
\hline \multicolumn{4}{|l|}{ Phylum Zoomastigophora } \\
\hline Class Choanoflagellidea & Bicosta spinifera $^{\mathrm{d}}$ & Monosiga marina & \\
\hline$: \mathrm{H}$ & $\begin{array}{l}\text { Callicantha natans }^{\mathrm{d}} \\
\text { Desmerella moniliformis } \\
\text { Monosiga marina } \\
\text { M. micropelagica }\end{array}$ & Parvicorbicula socialis & \\
\hline $\begin{array}{l}\text { Class Kinetoplastidea } \\
: \mathrm{H}\end{array}$ & Telonema subtilis & Telonema subtilis & \\
\hline $\begin{array}{l}\text { Unidentified flagellates } \\
: \mathrm{P} / \mathrm{H} / \mathrm{M}\end{array}$ & Flagellates indet & Flagellates indet & Flagellates indet \\
\hline
\end{tabular}

Class Prymnesiophyceae

: $\mathrm{P} / \mathrm{H} / \mathrm{M}$

Class Crysophyceae

$: \mathrm{P} / \mathrm{H} / \mathrm{M}$

Class Cryptophyceae

Class Rhaphidophyceae

Euglenophycea

Chloroplasts lacking

b Ejectosomes

c Mucocysts

${ }^{\mathrm{d}}$ Size information in literature not in concert with measured size in our analysis and $80 \mathrm{mg} \mathrm{C} \mathrm{m}^{-2} \mathrm{~d}^{-1}$ in July and September, respectively. $\mathrm{PP}$ was not measured in December.

Low integrated BP was observed in March, September and December (<30 mg C m $\mathrm{m}^{-2} \mathrm{~d}^{-1}$; Fig. 5). Integrated BP peaked in April (170 $\left.\mathrm{mg} \mathrm{C} \mathrm{m}^{-2} \mathrm{~d}^{-1}\right)$ and remained moderately high in May (90 $\mathrm{mg} \mathrm{C} \mathrm{m}^{-2} \mathrm{~d}^{-1}$ ) and July (110 $\mathrm{mg} \mathrm{C} \mathrm{m}^{-2} \mathrm{~d}^{-1}$ ).

Integrated PP and BP followed the same temporal trend and displayed a comparable production level in March, July and September (Fig. 5). In April and May, heterotrophic 
Table 4 Integrated (0-50 m) particulate organic carbon (POC; mg C $\mathrm{m}^{-2}$ ) and relative contribution to POC (\% POC) by different compartments of the microbial food web (heterotrophic bacteria, picoplankton, nanoflagellates, dinoflagellates and ciliates) in the upper $50 \mathrm{~m}$ of Kongsfjorden during sampling in March, April, May, July, September and December 2006. Relative contribution by dinoflagellates and ciliates is calculated from biomass presented in Seuthe et al. (accepted)

\begin{tabular}{lrrllll}
\hline & \multirow{2}{*}{$\begin{array}{l}\text { Total POC } \\
\mathrm{mg} \mathrm{C} \mathrm{m}^{-2}\end{array}$} & $\%$ POC & \multicolumn{7}{l}{ Bacteria Picoplankton } & Nanoflag & Dinoflag Ciliates \\
\cline { 3 - 7 } & & 3 & 0 & 0.5 & 1 & 2.5 \\
Mar & 4,050 & 3 & 0 & 45 & 5 & 2 \\
Apr & 32,350 & 1 & 1 & 1 & 0.5 \\
May & 15,550 & 17 & 0 & 10 & 0.5 & 1.5 \\
Jul & 12,500 & 16 & 1.5 & 3 & 3.5 & 3 \\
Sep & 5,300 & 10 & 0.5 & 1.5 & 3.5 & 4.5 \\
Dec & 2,150 & 8 & 0 & &
\end{tabular}

Table 5 Relative contribution (\%) of integrated biomass of total phototrophic (PPC; $\mathrm{mg} \mathrm{C} \mathrm{m}^{-2}$ ) to total integrated particulate organic carbon (POC; $\mathrm{mg} \mathrm{C} \mathrm{m}^{-2}$ ) and relative contribution (\% PPC) of integrated biomass of phototrophic picoplankton and nanoflagellates to PPC in the upper $50 \mathrm{~m}$ of Kongsfjorden during sampling in March, April, May, July, September and December 2006

\begin{tabular}{llll}
\hline & PPC:POC $(\%)$ & $\%$ PPC \\
\cline { 3 - 4 } & & Picoplankton & Nanoflag \\
\hline Mar & 1.5 & $<0.5$ & 25 \\
Apr & 65 & $<0.5$ & 70 \\
May & 2.5 & $<1.0$ & 35 \\
Jul & 15 & 10 & 35 \\
Sep & 5.0 & 10 & 35 \\
Dec & 2.5 & $<0.5$ & 15 \\
\hline
\end{tabular}

bacteria and phototrophic plankton were disconnected when it came to carbon production. The relationship between $\mathrm{BP}$ and PP was $\gg 1$ in March and $<1$ in the four other months with PP data available (Fig. 5). The lowest BP:PP ratio was observed in May (0.2) and the highest in July (0.7).

Structuring factors of the microbial food web throughout the Kongsfjord year

Multivariate statistical analysis revealed that the N:P ratio, salinity, temperature and total protozooplankton explained $67.9 \%$ of the total variation in the dependent variables (Monte Carlo test, $P=0.005$; Fig. 6). The parameters represented within the microbial food web grouped into different segments, based on the correlation between them. BP and phototrophic nanoflagellates were closely related, which was also the case for bacterial abundance and heterotrophic nanoflagellates. Phototrophic picoplankton was loosely associated with heterotrophic picoplankton and bacterial abundance/heterotrophic nanoflagellates. PP could
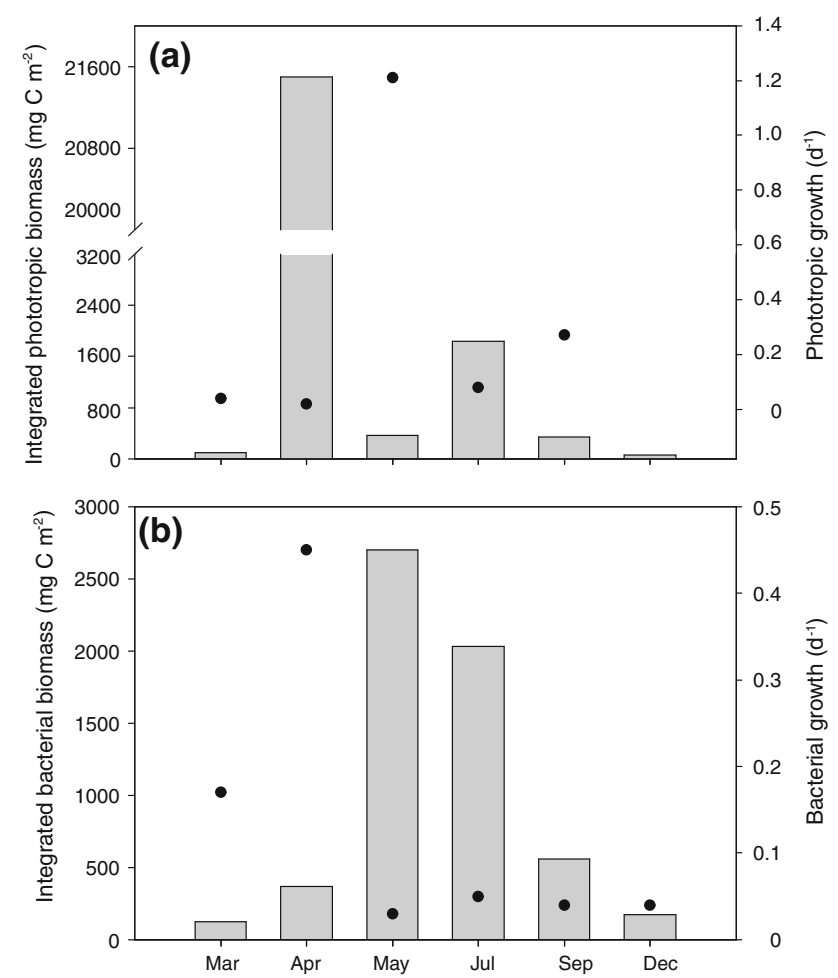

Fig. 4 Integrated biomass (mg $\mathrm{C} \mathrm{m}^{-2}$; vertical bars) and specific growth rates $\left(\mathrm{d}^{-1}\right.$; filled circles) of (a) total phototrophic plankton (including phototrophic picoplankton, nanoflagellates and dinoflagellates, diatoms and all other taxonomic groups) and (b) heterotrophic bacteria, in the upper $50 \mathrm{~m}$ of Kongsfjorden during sampling in March, April, May, July, September and December 2006. Note the different scales

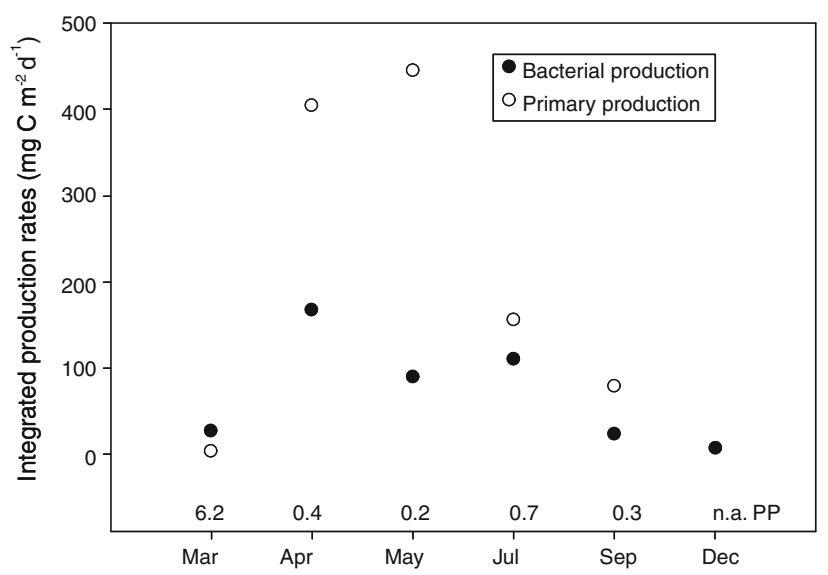

Fig. 5 Integrated primary (PP; open circles) and bacterial production (BP; filled circles) in $\mathrm{mg} \mathrm{C} \mathrm{m}^{-2} \mathrm{~d}^{-1}$ in the upper $50 \mathrm{~m}$ in Kongsfjorden, Svalbard, during sampling in March, April, May, July, September and December 2006. Primary production rates were not measured in December

unfortunately not be included in the analyses due to missing values in December.

The significant model showed that a low N:P ratio was associated with the microbial food web as a whole (Fig. 6). Bacterial abundance, BP and heterotrophic nanoflagellates 


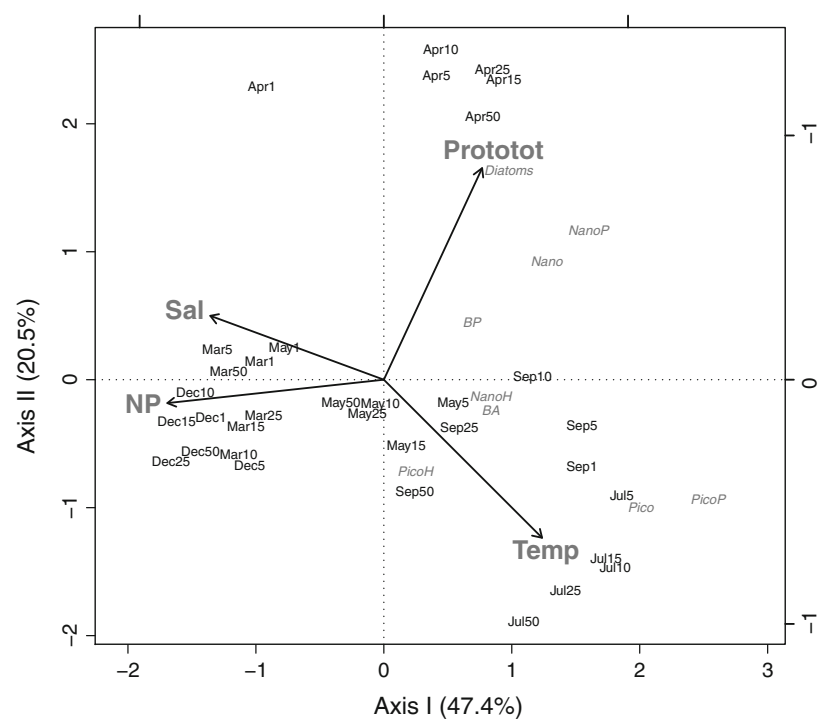

Fig. 6 Biplot of ordination model (RDA) results showing how response variables (bacterial abundance $(B A)$, bacterial production $(B P)$ and abundances of total picoplankton (Pico), phototrophic picoplankton $($ PicoP $)$, heterotrophic picoplankton $(\mathrm{PicoH})$, total nanoflagellates (Nano), phototrophic nanoflagellates (NanoP), heterotrophic nanoflagellates $(\mathrm{NanoH})$ and diatoms (Diatoms)) related to the environmental variables salinity $(\mathrm{Sal})$, temperature (Temp), the nitrogen:phosphate ratio $(N P)$ and both dinoflagellates and ciliates (Prototot) in the sampled months in Kongsfjorden 2006. See Method section for biplot interpretation. The model shows how (1) all microbial organism groups were related to low $\mathrm{N}: \mathrm{P}$ ratio, (2) $\mathrm{BA}, \mathrm{BP}$ and heterotrophic nanoflagellates were closely related to low $\mathrm{N}: \mathrm{P}$, (3) picoplankton, and in particular phototrophic picoplankton, were closely related to low salinity and higher temperatures and (4) diatoms and phototrophic nanoflagellates were associated with each other and protozooplankton

were closely related to the low N:P ratio. The multivariate analysis revealed a strong positive correlation between low salinity, higher water temperature, and total picoplankton, and the phototrophic fraction in particular. Picoplankton were closer associated with the physical properties of the water masses than with $\mathrm{N}: \mathrm{P}$ ratio and potential predators in the protozooplankton. The multivariate analysis displayed a close relationship between the environmental variable of protozooplankton and phototrophic nanoflagellates and diatoms as response variables. Heterotrophic bacteria and picoplankton were not associated with protozooplankton.

\section{Discussion}

Despite a few investigations focusing on specific aspects of the microbial food web in the Barents Sea region (e.g. Hansen et al. 1996; Verity et al. 2002; Sturluson et al. 2008) and the adjacent water masses in Kongsfjorden (e.g. Jankowska et al. 2005; Thingstad et al. 2008; Wang et al. 2009), hitherto no investigations on seasonal dynamics of the microbial food web in the European Arctic have been carried out, to our knowledge. Our seasonal data from Kongsfjorden indicate that small organisms $(<20 \mu \mathrm{m})$ are pivotal components in both ecosystem structure and function during different ecological scenarios in the annual cycle. Distinct seasonal patterns in biomass, productivity and ecological impact of specific groups of organisms were observed, partly controlled by the physical environment, nutrient conditions and trophic cascading effects.

Seasonal significance of the microbial food web in Kongsfjorden

A seasonal comparison of integrated biomass and production rates in Kongsfjorden (Fig. 7) highlighted an apparent difference in structure and function of the microbial food web under spring-bloom conditions when compared with the other seasons. The spring bloom in April was characterised by new production (excess nitrate available), while nitrate depletion initiated a scenario where production must have been regenerated and fuelled by nitrogen sources like ammonium and urea (Eppley and Peterson 1979). In the winter months, high concentrations of nutrients co-occurred with low irradiance, limiting photosynthetic processes and new production. Subsequently, total heterotrophic biomass (bacteria and protozooplankton) dominated the food web in all months except April (Fig. 7a). However, PP was substantially higher (20-70\%) than BP in all months but March and most likely December (Fig. 7b). In the following, the structure and functioning of the microbial food web will be discussed in more detail for the months sampled.

\section{Spring bloom in April: strong microbial signal}

The activity within the microbial food web in Kongsfjorden peaked under the spring bloom in April, as illustrated through high BP and high biomass of single cells of the nanoflagellate Phaeocystis pouchetii. Dinoflagellates and ciliates were highly abundant in the same period, most likely due to reduced predation pressure by a low standing biomass of mesozooplankton (Seuthe et al. accepted), as often observed in Kongsfjorden (Willis et al. 2006). The high biomass of protozooplankton in April-May probably led to cascading effects within the microbial food web. For example, low integrated bacterial biomass, in conjunction with high bacterial specific growth rates, implies that heterotrophic bacteria were heavily subjected to removal processes, such as protozooplankton predation (e.g. Sherr et al. 1989) or viral infections (e.g. Weinbauer 2004). In fact, high biomass and potential grazing rates suggest that heterotrophic dinoflagellates and ciliates probably were the principal grazers under the spring bloom in Kongsfjorden (Seuthe et al. accepted). Scenarios as described here can demonstrate an alternative to the paradigm regarding 
(a)

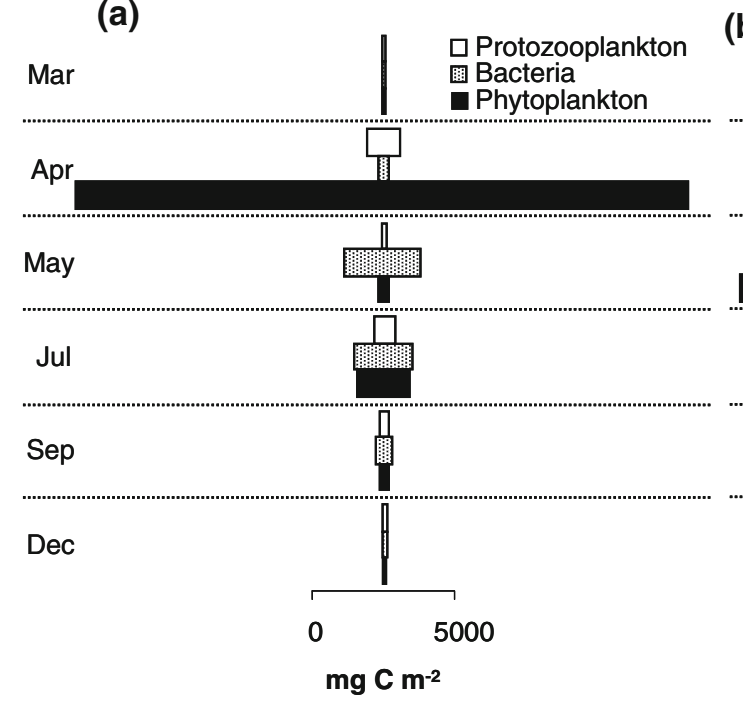

(b)

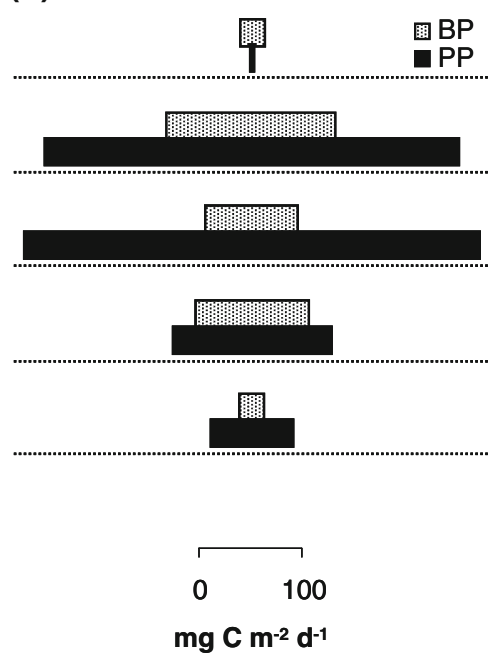

Fig. 7 Comparison of integrated (a) biomass $\left(\mathrm{mg} \mathrm{C} \mathrm{m}^{-2}\right)$ of total phytoplankton (including diatoms and phototrophic dinoflagellates, according to Seuthe et al. (accepted); black horizontal bars), heterotrophic bacteria (dark grey horizontal bars) and total protozooplankton (including heterotrophic dinoflagellates and heterotrophic and mixotrophic ciliates, according to Seuthe et al. (accepted) in Polar Biology;

large-celled phytoplankton and the classical food chain as dominant features of the vernal bloom. Our observations in Kongsfjorden are thus in agreement with reports from relevant studies in Disko Bay, western Greenland (Nielsen and Hansen 1995), and the central Barents Sea (Hansen et al. 1996), showing that the microbial food web contributes substantially to ecosystem structure and functioning also under spring-bloom conditions, especially when mesozooplankton are less abundant.

\section{Post-bloom conditions in May: efficient microbial loop}

Under the post-bloom conditions in May, low concentrations of nutrients were observed in combination with high concentrations of DOC. Maximum integrated PP was encountered in combination with low phytoplankton biomass and chl $a<10 \mu \mathrm{m}$ dominating the chl $a$ biomass. According to Seuthe et al. (accepted), mesozooplankton were present in Kongsfjorden in May. The high specific growth rate calculated for phototrophic plankton suggests that mesozooplankton were grazing actively on the phototrophic plankton. Relatively low biomass of protozooplankton further suggests that mesozooplankton also preyed upon this functional group, a well-established link (Calbet and Saiz 2005), with regulatory impact also in Arctic regions (Levinsen and Nielsen 2002). It could be expected that a low biomass of protozooplankton would relieve heterotrophic nanoflagellates from top-down regulation, enabling them to graze efficiently on heterotrophic bacteria. Heterotrophic nanoflagellates were, however, surprisingly light grey horizontal bars) and (b) primary (PP; black horizontal bars) and bacterial production (BP; dark grey horizontal bars) in the upper $50 \mathrm{~m}$ of Kongsfjorden during sampling in March, April, May, July, September and December 2006. Primary production rates were not measured in December

absent in the post-bloom scenario in Kongsfjorden. Meroplankton constituted a dominant feature of the zooplankton in May (Seuthe et al. accepted), including for instance Oithona spp. nauplii and meroplankton larvae (e.g. verliger and pluteus larvae) thought to prey on nanoflagellates (Pasternak et al. 2008; Bottjer et al. 2010). In agreement with the low biomass of bacteriovorous predators, heterotrophic bacteria thrived in the post-bloom conditions in Kongsfjorden. Moderate integrated production rates, high biomass and low specific growth rates for heterotrophic bacteria confirm that they were not subjected to strong grazing pressure during this period, while substrate supply and/or competition for nutrients could have been limiting for bacterial production.

Mesozooplankton preying on phototrophic plankton and protozooplankton could represent a constant supply of DOC from sloppy feeding, with positive implications for heterotrophic bacteria (Møller et al. 2003) and the microbial loop (Azam et al. 1983). The high bacterial biomass under conditions with low nutrient concentrations could facilitate primary production through remineralisation of limiting nutrients (Legendre and Rassoulzadegan 1995). The integrated biomass of POC in May was 50\% of that in April, while integrated primary production was higher in May. This could indicate fast turnover of produced carbon, increasing the production in nutrient-poor surface waters and reducing accumulation of organic carbon. The observed ecological processes were facilitated by mesozooplankton and heterotrophic bacteria through efficient grazing and remineralisation of nutrients and DOC, shaping the 
framework of an efficient microbial loop. Our investigation suggests that the microbial food web held a significant position in the pelagic ecosystem under post-bloom conditions in Kongsfjorden, and corroborate observations from western Greenland (Levinsen et al. 1999; Nielsen and Hansen 1999) and other Arctic areas, like the central Arctic Ocean (Sherr et al. 2003) and the Western Arctic Ocean (Sherr et al. 2009).

\section{Stratified water masses: microbial fundament for alternative pathways in July and September}

In July, the water column became strongly stratified, with low nutrient and relatively high DOC concentrations prevailing in the shallow surface layer. Relatively high and comparable integrated phototrophic and bacterial biomass were combined with an almost twice as high growth rate of phototrophic plankton as that of heterotrophic bacteria. This could imply a situation similar to the post-bloom scenario in May, when heterotrophic bacteria had been released from grazing pressure and remineralised limiting nutrients for phototrophic production. Heterotrophic nanoflagellates, however, accounted for $87 \%$ of the high integrated biomass of protozooplankton in Kongsfjorden in summer ( $635 \mathrm{mg} \mathrm{C} \mathrm{m}^{-2}$; Seuthe et al. accepted). Since heterotrophic nanoflagellates could prey efficiently on bacteria (Vaqué et al. 2008), their high biomass may indicate potential heavy grazing on the bacterial population. Picoplankton might, however, be an alternative prey-organism for heterotrophic nanoflagellates (e.g. Chen and Liu 2010), which could explain the growth-rate discrepancies seen between phototrophic plankton and heterotrophic bacteria. Heterotrophic dinoflagellates and ciliates contributed substantially less in July than in the other seasons (4-8\%), and Seuthe et al. (accepted) also observed that larger copepods dominated $(90 \%)$ the mesozooplankton biomass in summer. Since picoplankton and nanoflagellates are smaller than the assumed minimum prey-size of copepods in Arctic systems (5-10 $\mu \mathrm{m}$ depending on species; Levinsen et al. 2000a), it is highly likely that other predators were actively preying on the microbial food web. Web-feeding pteropods and appendicularians could be potential grazers of picoplankton and even nanoflagellates (Fortier et al. 1994; Acuña and Deibel 1996). Aggregation of picoplankton in mesozooplankton guts has recently also been reported, probably due to repacking of ingested faecal pellets and aggregates (Wilson and Steinberg 2010). Viral infections are also known to induce lysis and increase mortality and can influence the loss rates in the microplankton community (e.g. Weinbauer 2004). The relatively high BP:PP of 0.7 further suggests that heterotrophy was more prominent in July than in the other seasons. High biomass of bacteria, picoplankton and heterotrophic nanoflagellates, low biomass of dino- flagellates and ciliates, and the potential presence of alternative predators certainly indicate alternative and unresolved routes for carbon flow in Kongsfjorden in stratified water masses.

In September, increased concentrations of nutrients supported a modest biomass of phototrophic plankton in the surface waters, where picoplankton and nanoflagellates accounted for 10 and $35 \%$ of PPC, respectively. In addition, diatoms and phototrophic dinoflagellates contributed to PPC (Seuthe et al. accepted). As in July, PPC was comparable with biomass of heterotrophic bacteria, while the specific growth rate of phototrophic plankton was $>50 \%$ higher than bacterial growth rates. In September, however, heterotrophic dinoflagellates and ciliates each contributed with $40 \%$ of total protozooplankton $\left(323 \mathrm{mg} \mathrm{C} \mathrm{m}^{-2}\right.$; Seuthe et al. accepted). Large copepods dominated the low biomass of mesozooplankton. Based on the combination of parameters, it could be interpreted that the microbial food web was in a steady state in September. Protozooplankton was grazing on bacteria, picoplankton and nanoflagellates, while a small population of mesozooplankton preyed upon diatoms and protozooplankton. Under these circumstances, the classical food chain and the microbial loop occurred concurrently, routing carbon to higher trophic levels by two alterative, and interweaving, pathways.

\section{Winter scenarios in March and December: a persistent microbial food web}

The microbial community in Kongsfjorden persisted at low levels throughout the polar night, as shown previously in western Greenland (Levinsen et al. 2000b), the central Arctic Ocean (Sherr et al. 2003), and southeastern Beaufort Sea (Terrado et al. 2008). Interestingly, the community structure differed between the start and end of the polar night. While integrated phototrophic plankton abundances and biomass were higher in March than in December, integrated biomass of heterotrophic bacteria, picoplankton and nanoflagellates were, on the other hand, lower in March than in December. In March, long day length $\left(>12 \mathrm{~h} \mathrm{~d}^{-1}\right)$ and high concentrations of inorganic nutrients favoured small phototrophic plankton $<20 \mu \mathrm{m}$. Nevertheless, BP remained higher than PP, probably due to qualitative and quantitative properties of irradiance this early in the season (e.g. Sakshaug et al. 2009). In December, under $24 \mathrm{~h}$ of darkness, higher abundances of the microbial players coincided with a more pronounced contribution of heterotrophic cells in the picoplankton and nanoflagellate populations. This may indicate that the system had settled in a heterotrophic state for the polar winter. Elevated levels of DOC in December when compared with March may suggest that DOC and dissolved organic matter (DOM) accumulated during spring and summer served as a carbon reserve for the microbial food 
web during the winter months, as shown in lower latitude seas (Sintes et al. 2010). We do not know whether the DOC present in winter moths in Kongsfjorden was of refractory or labile character. The combination of available DOC and a microbial food web in a heterotrophic state nevertheless suggests that the microbial food web was capable of continuing its ecological processes also under winter conditions.

Different microbial players in the carbon cycling in Kongsfjorden

\section{Heterotrophic bacteria: important contributors to carbon production and biomass}

Heterotrophic bacteria were important contributors to both carbon production and biomass in Kongsfjorden. Bacterial abundance was in the same numerical range as in other high-latitude locations $\left(\sim 0.2-4 \times 10^{6}\right.$ cells $\mathrm{ml}^{-1}$; e.g. Nielsen and Hansen 1995; Sherr et al. 1997; Howard-Jones et al. 2002; Garneau et al. 2008; Sturluson et al. 2008) and displayed seasonal variation, with maximum abundances during post-bloom conditions. Further, integrated bacterial biomass was calculated to 2,700 and $2,000 \mathrm{mg} \mathrm{C} \mathrm{m}^{-2}$ in the post-bloom situation in May and July, corroborating earlier bacterial summer biomasses reported from Kongsfjorden (Jankowska et al. 2005; Wang et al. 2009), after correcting for different carbon conversion factors applied.

In our study, heterotrophic bacteria accounted for approximately $20 \%$ of total POC in May and July, when applying a carbon conversion factor of $12.4 \mathrm{fg} \mathrm{C} \mathrm{cell}^{-1}$. By applying an alternative carbon conversion factor, like the often used $20 \mathrm{fg} \mathrm{C}$ cell $^{-1}$, the relative contribution would have been altered. In addition, the carbon conversion factors assume identical bacterial size all times. In this context, size-information on heterotrophic bacteria from flow cytometry could add an interesting dimension. Side-scatter and fluorescence signals from flow cytometry indicated that bacterial cells present during the spring bloom in April was relatively larger and had a relatively higher content of DNA than bacterial cells found in other seasons (data not shown). Such seasonal differences within the bacterial community have implications for the ecological role of heterotrophic bacteria and the microbial food web and should be further investigated.

In Kongsfjorden, integrated BP showed that $90-165 \mathrm{mg}$ $\mathrm{C} \mathrm{m}^{-2} \mathrm{~d}^{-1}$ was processed by heterotrophic bacteria in the upper water column in April, May and July (Fig. 7b). Maximum integrated bacterial production rates were measured during the phytoplankton bloom in April $\left(165 \mathrm{mg} \mathrm{C} \mathrm{m}^{-2}\right.$ $\left.\mathrm{d}^{-1}\right)$. The measured rates obtained during the different seasons covered in Kongsfjorden are comparable to seasonspecific reports from other high-latitude waters (e.g.
Müller-Nicklas and Herndl 1996; Møller and Nielsen 2000; Howard-Jones et al. 2002; Sturluson et al. 2008), when correcting for different leucine conversion factors applied. Garneau et al. (2008) did, however, report a seasonal range of BP from coastal western Canadian Arctic substantially lower (1-80 $\mathrm{mg} \mathrm{C} \mathrm{m}^{-2} \mathrm{~d}^{-1}$ ) than the ones observed in Kongsfjorden. Coastal arctic ecosystems are heterogenous both in a temporal (e.g. interannual) and spatial (different geographical areas within the Pan-Arctic region) context, and biological processes, like BP, probably mirror such heterogeneity.

The BP:PP ratio implied that heterotrophic bacteria processed $20-70 \%$ of the carbon produced by phototrophic plankton in April, May, July and September. These ratios were substantially exceeded in March, displaying a BP:PP ratio of $620 \%$. This extreme ratio was probably due to the special conditions in March, when PP was still limited by the light conditions, while $\mathrm{BP}$ was fuelled by inorganic nutrients and moderate levels of DOC. Nevertheless, all BP:PP ratios from Kongsfjorden are within the range reported from polar waters previously (e.g. Ducklow and Carlson 1992; Sturluson et al. 2008; Kirchman et al. 2009a).

The BP:PP ratio should, however, be considered in combination with bacterial carbon demand (BCD) and bacterial growth efficiency (BGE). Averaged BGE in the world's ocean is assumed to be $15 \%$ (del Giorgio and Cole 2000). If considering the high BP:PP ratios in Kongsfjorden applying a BGE of $15 \%$, it would imply that heterotrophic bacteria process $\gg 100 \%$ of PP. In the current work, however, the literature BGE was not applied. Instead, BGE was estimated based upon the empirically measured BP. Initially, bacterial respiration (BR) was computed from the formula $\mathrm{BR}=3.69 \times \mathrm{BP}^{0.58}$ (Robinson 2008). $\mathrm{BCD}$ was further estimated from the formula $\mathrm{BCD}=\mathrm{BP}+\mathrm{BR}$, and finally $\mathrm{BGE}$ was calculated as $\mathrm{BGE}=\mathrm{BP} /(\mathrm{BP}+\mathrm{BR}$ ) (Robinson 2008). According to this approach, the BGE in Kongsfjorden ranged between 37 and 70\% (Table 6), which is considerable higher than BGE reported from the western Arctic Ocean (6.9\%; Kirchman et al. 2009a), while the lower range overlap with BGE observed in the Kara Sea (27\%; Meon and Amon 2004) and statistical predictions for a temperature of $0^{\circ} \mathrm{C}$ (37\%; Rivkin and Legendre 2001). High BGE implies that the heterotrophic bacteria in Kongsfjorden utilized their produced carbon efficiently for growth in 2006.

When estimating bacterial consumption of $\mathrm{PP}$ as $\mathrm{BCD}$ relative to $\mathrm{PP}$, heterotrophic bacteria processed $30-1,200 \%$ of PP in Kongsfjorden (Table 6). It was interesting to notice that while $\mathrm{BR}, \mathrm{BCD}$ and $\mathrm{BGE}$ all were highest in parallel to the spring bloom in April, bacterial consumption of PP was intermediate $(60 \%)$ when compared with the stratified summer situation in July $(110 \%)$. The lowest relative 
Table 6 Estimates of bacterial respiration (BR; $\mathrm{mg} \mathrm{C} \mathrm{m}^{-2} \mathrm{~d}^{-1}$ ), bacterial carbon demand (BCD) and bacterial growth efficiency (BGE; \%) in the upper $50 \mathrm{~m}$ of Kongsfjorden during sampling in March, April, May, July, September and December 2006. Bacterial consumption of primary production (PP) as $\mathrm{BCD}$ relative to $\mathrm{PP}(\mathrm{BCD}: \mathrm{PP} ; \%)$ was also estimated. Average water temperature $\left({ }^{\circ} \mathrm{C}\right)$ is also presented. Primary production rates were not measured in December

\begin{tabular}{lccrll}
\hline & ${ }^{\circ} \mathrm{C}$ & $\mathrm{BR}$ & $\mathrm{BCD}$ & $\mathrm{BGE}(\%)$ & $\mathrm{BCD}: \operatorname{PP}(\%)$ \\
\hline Mar & 0.7 & 25 & 51 & 52 & 1,200 \\
Apr & 0.5 & 72 & 239 & 70 & 60 \\
May & 2.0 & 50 & 141 & 64 & 30 \\
Jul & 4.0 & 56 & 167 & 66 & 110 \\
Sep & 4.5 & 23 & 46 & 50 & 60 \\
Dec & 1.5 & 11 & 18 & 38 & NA \\
\hline
\end{tabular}

consumption of PP by bacteria was observed in the postbloom situation in May (30\%), while the highest BCD when compared with PP was found in March $(1,200 \%)$. $\mathrm{BCD}$ exceeding primary production could be explained by only particulate PP being measured with the applied methods, while also dissolved PP adds to total PP (Vernet et al. 1998). Additionally, both PP and BP data are 1-day estimates and variability in production rates could be of importance. An advective system as Kongsfjorden further subjects both data and interpretations to the challenge of parameters, such as $\mathrm{PP}$ and $\mathrm{BP}$, potentially being disconnected in time and space.

Their seemed to be no obvious correlation between bacterial parameters derived from BP with water temperature or $\mathrm{PP}$, which have been proposed from previously observations (e.g. Kirchman et al. 2009a, b). Another factor co-varying with temperature could, however, very well have influenced bacterial processes in Kongsfjorden. Kirchman et al. (2009b) suggested DOC as a clear candidate for such a co-varying factor. Even though DOC levels seemed stabile after the spring bloom in Kongsfjorden, the composition and availability of the DOC is unknown. The $\mathrm{C}: \mathrm{N}$ ratios may imply that the majority of carbon present in Kongsfjorden was of marine origin. Our multivariate statistical analysis also shows that BP was correlated with low $\mathrm{N}: \mathrm{P}$ ratio and protozooplankton in Kongsfjorden. This is interesting, since protozooplankton could be associated with DOC supply through grazing activity, as was probably seen in the post-bloom situation in May. Low N:P ratio does, however, indicate limited inorganic nutrients, which would enhance the competition between heterotrophic bacteria and phototrophic plankton for available substrate. The coupling between inorganic nutrients and carbon and its impact on heterotrophic bacteria and the microbial food web is, however, a complicated one, as described by the counterintuitive findings in Kongsfjorden of Thingstad et al. (2008).
Picoplankton: important for trophic structures but not for carbon flux?

Phototrophic picoplankton constituted a major part of the total phototrophic plankton abundance in Kongsfjorden during summer and autumn stratification in 2006. The abundances observed in Kongsfjorden were in the same range as picoeukaryote abundances in other Arctic regions (e.g. Booth and Horner 1997; Not et al. 2005; Tremblay et al. 2009). The high abundance of picoplankton in Kongsfjorden coincided with summer and autumn stratification due to enhanced freshwater discharge from land. In addition, nitrate concentrations were non-detectable in July, when maximum picoplankton abundance was encountered. Low salinities and nitrate limitation have been reported to facilitate picoplankton success during autumn in other Arctic localities, such as in the southeastern Beaufort Sea (Schloss et al. 2008). Our multivariate statistical analyses also confirmed that picoplankton in Kongsfjorden were more closely related to low salinity and higher water temperatures than to low nitrate-to-phosphate (N:P) ratio (Fig. 6).

The small size of picoeukaryotes and picocyanobacteria results in surface-to-volume ratios favourable under conditions where nutrients are limited. In addition, picocyanobacteria have the ability to utilize a wide variety of nitrogen sources (e.g. Vincent 2002). The maximum picoplankton concentrations found in July were higher than reported from other localities, but were comparable with the highest values reported from Kongsfjorden in August 2006 (Wang et al. 2009). As Wang et al. (2009), we did not distinguish between picoeukaryotes and picocyanobacteria within the picoplankton. While cyanobacteria are generally thought not to be abundant in polar waters, Cottrell and Kirchman (2009) observed them in the western Arctic. Not et al. (2005) also reported that the numerical importance of picocyanobacteria increased when moving from Arctic to Atlantic water masses in the Barents Sea. A strong inflow of Atlantic water into Kongsfjorden was recorded by an oceanographic mooring in the entrance of the fjord in the middle of July 2006 (F. Cottier, personal communication). It is therefore likely that picocyanobacteria were present in Kongsfjorden in summer and autumn 2006, which could explain the high abundance of picoplankton recorded in our study.

The considerable picoplankton abundance suggests that they had an important ecological function in the trophic structure in Kongsfjorden during summer stratification. The contribution of picoplankton to carbon biomass was, however, less obvious. Picoplankton did not contribute considerably to POC even in the months where high picoplankton abundance was observed. At maximum, picoplankton biomass accounted for $<2 \%$ of POC (July), while the relative contribution in September was $\leq 0.5 \%$. The POC contributions 
from picoplankton are still in the same range as for dinoflagellates $(0.5-5 \%)$ and ciliates $(0.5-4.5 \%)$ (Seuthe et al. accepted). Compared to heterotrophic bacteria (maximum $17 \%$ ) and phototrophic nanoflagellates (maximum 45\%), the relative importance of picoplankton to POC in Kongsfjorden was negligible. However, integrated PPC only comprised 15 and $5 \%$ of POC in July and September, respectively, of which picoplankton and nanoflagellates constituted 10 and 35\%. Thus, phototrophic picoplankton contributed to phytoplankton biomass during the summer stratification in Kongsfjorden.

In Kongsfjorden, picoplankton could have contributed substantially to carbon turnover in July and September, when high abundances of phototrophic picoplankton coincided with moderate integrated PP rate and small cells accounted for more than $85 \%$ of total chl $a$. Small cells $(<10 \mu \mathrm{m})$ also contributed substantially to PP in the northern Barents Sea despite a lower share in biomass, especially in early and late bloom scenarios (Hodal and Kristiansen 2008). The fast turnover in picoplankton cells may further result in a larger contribution to PP than their biomass suggests (Agawin et al. 2000). Results from inverse and network analyses from lower latitudes do suggest that picoplankton can contribute to carbon fluxes proportional to their total PP (Richardson and Jackson 2007). It is therefore likely that picoplankton contributed considerably to PP and carbon dynamics also in Kongsfjorden.

Picoplankton in Kongsfjorden thrived at low N:P ratio in warm and fresh water in the stratified summer situation. Our multivariate statistical analysis thus implies that these minute organisms can benefit from climate-induced alterations in physical and biochemical properties of Kongsfjorden and adjacent water masses in the Arctic, as proposed by Li et al. (2009). Extended periods of stratified water masses with lower nutrient concentrations and warmer and fresher water can thus have implications for ecosystem structure and function, as well as carbon dynamics in high-latitude fjords like Kongsfjorden.

\section{Nanoflagellates: more than Phaeocystis pouchetii?}

Nanoflagellates contributed substantially to both ecosystem structure and carbon biomass in Kongsfjorden, as indicated by the massive contribution of P. pouchetii to POC in April (45\%). Since single cells of $P$. pouchetii fall into the category of small phytoplankton cells $(<10 \mu \mathrm{m})$, the importance of this nanoflagellate for both carbon production and biomass in Kongsfjorden corroborates the ecological impact of small phototrophic cells in other Arctic regions (e.g. Legendre et al. 1993; Gosselin et al. 1997; Mei et al. 2003; Brugel et al. 2009).

$P$. pouchetii constitutes an important ecological component in Arctic water masses, as in the productive Barents
Sea (e.g. Verity et al. 1999; Rat'kova and Wassmann 2002; Not et al. 2005; Hodal and Kristiansen 2008), where single cells and colonies (up to $2 \mathrm{~mm}$ ) of $P$. pouchetii can form massive blooms and occasionally contribute to downward flux of carbon (Wassmann et al. 2005; Reigstad and Wassmann 2007). The weak stratification present in the water column in Kongsfjorden during the spring bloom in April probably allowed deep mixing to occur. Due to potential adaption to low irradiance, $P$. pouchetii seems well adapted to form blooms under physical conditions as the ones encountered in Kongsfjorden (Jacobsen et al. 1995; Reigstad et al. 2002). As seen before during blooms of $P$. pouchetii in the Barents Sea (Reigstad et al. 2002), concentrations of nitrate and silicate in Kongsfjorden revealed a skewed temporal depletion. While nitrate was depleted in April, concentrations of silicate $>3 \mu \mathrm{M}$ were still encountered. This could indicate that $P$. pouchetii was the major primary producer during the spring bloom in Kongsfjorden, while the silicate-based carbon production through diatoms in comparison was lower. It has been proposed that the ratio between single and colonial cells is induced by top-down regulation (Tang 2003), reflecting for instance the poor ability of mesozooplankton to feed upon single cells (Wassmann et al. 2005). During the spring bloom in Kongsfjorden, mesozooplankton were, however, not numerically abundant (Seuthe et al. accepted). Other factors must therefore have induced the single-cell mode observed. Small cells are known to exudate a larger fraction of their stored DOM than communities of larger cells do (e.g. Kiørboe 1993). Single cell $P$. pouchetii blooms could therefore potentially have facilitated the success of heterotrophic bacteria and the microbial food web through enhanced DOC supply, with implications for carbon dynamics and trophic structure.

Nanoflagellates also accounted for $10 \%$ of POC in July, when the nanoflagellate population was almost evenly split between phototrophic and heterotrophic cells. Heterotrophic nanoflagellates constituted $87 \%$ of the total protozooplankton (heterotrophic picoplankton, nanoflagellates, ciliates and dinoflagellates) biomass in July (Seuthe et al. accepted) and thus probably were important grazers at this time of the year. Heterotrophic nanoflagellates in the sizerange $2-5 \mu \mathrm{m}$ were abundant in all seasons, constituting a significant loss factor for heterotrophic bacteria, and most likely also picoplankton, thus representing a link for organic carbon to higher trophic levels. The considerable contribution by phototrophic and heterotrophic nanoflagellates during the summer stratification is in concert with earlier observations in the Barents Sea (e.g. Rat'kova et al. 1999; Verity et al. 1999; Rat'kova and Wassmann 2002).

As a curiosity, viable cells of $P$. pouchetii were encountered in December, suggesting that the nanoflagellate was in a hetero- or mixotrophic stage of its complex life cycle 
during the polar night. Such findings suggest that trophic mode could facilitate both survival of the specific species and system viability in highly heterogeneous systems. Our data thus show how nanoflagellates can contribute substantially to ecosystem and carbon dynamics under seasonal scenarios as different as the spring bloom, summer stratification and winter conditions.

\section{Concluding remarks}

The current data on microbial organisms and processes in Kongsfjorden are part of the first seasonal investigation of the microbial food web in the European Arctic, to our knowledge. Our seasonal data show that heterotrophic bacteria, picoplankton and nanoflagellates contributed to both ecosystem structure and carbon dynamics in Kongsfjorden, as is probably also the case in the adjacent regions of the Svalbard archipelago, as the eastern Fram Strait.

The microbial food web constituted an active ecological segment in all seasons, including the spring bloom. The ecological significance of the different microbial organisms varied with season, as reflected by their stocks, rates and relative contribution to total POC.

Multivariate statistical analysis, seasonal comparisons of biomass and production and the seasonal ecological scenarios described suggest that nutrient concentration at large, and the N:P ratio specifically, affects the structure and function of the microbial food web bottom-up. Salinity and temperature also represented important structuring factors, for phototrophic picoplankton in particular. Heterotrophic bacteria and picoplankton were not associated with protozooplankton (ciliates and dinoflagellates) according to our analysis. Abundance of both these groups was, however, closely related to heterotrophic nanoflagellates. The fact that heterotrophic nanoflagellates did not seem to be associated with protozooplankton in our multivariate analysis is surprising. As top-down control undoubtedly influence all organisms in the microbial food web, our data set and analysis could not have covered and/or captured all potential predators, trophic interactions and complex trophic cascades sufficiently.

Our seasonal investigations showed that the microbial food web filled different roles in ecosystem structure and function throughout the seasons. In periods where factors as light and nutrients limited phototrophic production, the microbial food web appeared to be in a "regenerative mode", acting as remineralisator and sink of organic carbon. Under the spring bloom, new production generated through phototrophic activity was disconnected from the mesozooplankton in time and space. In this situation, an active microbial food web in "transfer mode" represented alternative routes and a link for organic carbon to higher trophic levels.
Our seasonal data thus support the classical view of the microbial food web being responsible for significant remineralisation through the microbial loop in periods of regenerated production. In addition, the microbial food web is capable of holding a central ecological position in periods of new production. If mesozooplankton is disconnected from the spring bloom and the new production spatially and/or temporarily, the microbial food web can act as a trophic link for organic carbon in time and space. Through the microbial food web's ability to fill different functional roles in periods dominated by new and regenerated production, microbial organisms and processes may enhance the ecological flexibility of pelagic ecosystems in the present era of climate change.

Acknowledgments Thanks are due to the crew of RV Jan Mayen and RV Lance, as well as the staff at the Marine Biological Laboratory and Kings Bay Company in Ny-Ålesund, Norway, and K. Dahle in particular. We are especially grateful to F. Cottier for hydrographical guidance, J. Dantović for analysis of DOC, S. Kristiansen for analysis of nutrients, T. Rat'kova for analysis of primulin-samples, R. Primicerio for statistical consultancies, F. Strand for graphic support, and R. Thyrhaug and A. Larsen for flow cytometry assistance. We would also like to thank P. Wassmann, T. F. Thingstad, M. Reigstad, A. Larsen, Carlos Pedrós-Alió and two anonymous reviewers for valuable comments on the manuscript. The map was created with help of the freeware program Ocean Data View. The ARCTOS network assisted with access to facilities and installations, as well as logistic support. This project was funded by Statoil in collaboration with ARCTOS, through the SAARP program (Unit I, a2) and MariClim, funded by the Norwegian Research Council under grant 165112/s30.

Open Access This article is distributed under the terms of the Creative Commons Attribution Noncommercial License which permits any noncommercial use, distribution, and reproduction in any medium, provided the original author(s) and source are credited.

\section{References}

ACIA (2004) Arctic climate impact assessment. Impact of a warming Arctic: Arctic climate impact assessment. Cambridge University Press, Cambridge, UK

Acuña JL, Deibel D (1996) Particle capture mechanism of the pelagic tunicate Oikopluera vanhoeffeni. Limnol Oceanogr 41:1800 1814

Agawin NSR, Duarte CM, Agustí S (2000) Nutrient and temperature control of the contribution of picoplankton to phytoplankton biomass and production. Limnol Oceanogr 45:591-600

Azam F, Fenchel T, Field JG et al (1983) The ecological role of watercolumn microbes in the sea. Mar Eco Prog Ser 10:257-263

Bloem J, Bär-Gilissen MJB, Cappenberg TE (1986) Fixation, counting, and manipulation of heterotrophic nanoflagellates. Appl Environ Microbiol 52:1266-1272

Booth BC, Horner RA (1997) Microalgae on the Arctic Ocean section, 1994: species abundance and biomass. Deep Sea Res II 44:16071622

Bottjer D, Morales CE, Bathmann U (2010) Trophic role of small cyclopoid copepod nauplii in the microbial food web: a case study in the coastal upwelling system of central Chile. Marine Biol 157:684-705 
Brugel S, Nozais C, Poulin M et al (2009) Phytoplankton biomass and production in the southeastern Beaufort Sea in autumn 2002 and 2003. Mar Eco Prog Ser 377:63-77. doi:10.3354/meps07808

Calbet A, Saiz E (2005) The ciliate-copepod link in marine ecosystems. Aquat Microb Ecol 38:157-167

Carmack E, Wassmann P (2008) Food webs and physical-biological coupling on pan-Arctic shelves: unifying concepts and comprehensive perspectives. Prog Oceanogr 71:446-477. doi:10.1016/ j.pocean.2006.10.004

Chen BZ, Liu HB (2010) Trophic linkages between grazers and ultraplankton within the microbial food web in subtropical waters. Mar Eco Prog Ser 407:43-53

Cottier FR, Nilsen F, Inall ME et al (2007) Wintertime warming of an Arctic shelf in response to large-scale atmospheric circulation. Geophys Res Lett 34:L10607. doi:10.1029/2007GL029948

Cottrell MT, Kirchman DL (2009) Photoheterotrophic microbes in the Arctic Ocean in summer and winter. Appl Environ Microbiol 75:4958-4966

del Giorgio PA, Cole JJ (2000) In: Kirchman DL (ed) Microbial ecology of the Ocean. Wiley-Liss, New York, pp 289-325

Ducklow HW, Carlson CA (1992) Oceanic bacterial production. In: Marshall KC (ed) Advances in microbial ecology. Plenum Press, New York, pp 113-181

Eppley RW, Peterson BJ (1979) Particulate organic matter flux and planktonic production in the deep ocean. Nature 282:677-680

Falk-Petersen S, Hop H, Budgell P et al (2000) Physical and ecological processes in the marginal ice zone of the northern Barents Sea during summer melt period. J Mar Syst 27:131-159

Fortier L, Le Fèvre J, Legendre L (1994) Export of biogenic carbon to fish and to the deep ocean: the role of large planktonic microphages. J Plankton Res 16:809-839

Fukuda R, Ogawa H, Nagata T et al (1998) Direct determination of carbon and nitrogen contents of natural bacterial assemblages in marine environments. Appl Environ Microbiol 64:3352-3358

Gargas E (1975) A manual for phytoplankton primary production studies in the Baltic. The Baltic Marine Biologists, Publication No. 2. The Danish Agency of Environmental Protection, Hørsholm

Garneau ME, Roy S, Lovejoy C et al (2008) Seasonal dynamics of bacterial biomass and production in a coastal arctic ecosystem: Franklin Bay, western Canadian Arctic. J Geophys Res Oceans 113:15

Gosselin M, Levasseur M, Wheeler PA et al (1997) New measurements of phytoplankton and ice algal production in the Arctic Ocean. Deep Sea Res II 44:1623-1644

Hansen B, Christiansen S, Pedersen G (1996) Plankton dynamics in the marginal ice zone of the central Barents Sea during spring: carbon flow and structure of the grazer food chain. Polar Biol $16: 115-128$

Hodal H, Kristiansen S (2008) The importance of small-celled phytoplankton in spring blooms at the marginal ice zone in the northern Barents Sea. Deep Sea Res II 55:2176-2185. doi:10.1016/ j.dsr2.2008.05.012

Hop H, Pearson T, Hegseth EN et al (2002) The marine ecosystem of Kongsfjorden, Svalbard. Polar Res 21:167-208

Howard-Jones MH, Ballard VD, Allen AE et al (2002) Distribution of bacterial biomass and activity in the marginal ice zone of the central Barents Sea during summer. J Mar Syst 38:77-91

Jacobsen A, Egge JK, Heimdal BR (1995) Effects of increased concentration of nitrate and phosphate during a springbloom experiment in mesocosm. J Exp Mar Biol Ecol 187:239-251

Jankowska K, Włodarska-Kowalczuk M, Wieczorek P (2005) Abundance and biomass of bacteria in two glacial fjords. Pol Polar Res 26:77-84

Kiørboe T (1993) Turbulence, phytoplankton cell size and the structure of pelagic food webs. Adv Mar Biol 29:1-62
Kirchman DL, K'Nees E, Hodson RE (1985) Leucine incorporation and its potential as a measure of protein synthesis by bacteria in natural aquatic systems. Appl Environ Microbiol 49:599-607

Kirchman DL, Hill V, Cottrell MT et al (2009a) Standing stocks, production, and respiration of phytoplankton and heterotrophic bacterial in the western Arctic Ocean. Deep Sea Res II 56:12371248. doi:10.1016/j.dsr2.2008.10.018

Kirchman DL, Morán XAG, Ducklow H (2009b) Microbial growth in the polar oceans-role of temperature and potential impact of climate change. Nat Rev 7:451-459. doi:10.1038/nrmicro2115

Larsen A, Castberg T, Sandaa RA et al (2001) Population dynamics and diversity of phytoplankton, bacteria and viruses in a seawater enclosure. Mar Ecol Prog Ser 221:47-57

Legendre P, Legendre L (1998) Numerical ecology, 2nd edn. Elsevier Science, BV, Amsterdam

Legendre L, Rassoulzadegan F (1995) Plankton and nutrient dynamics in marine waters. Ophelia 41:153-172

Legendre L, Gosselin M, Hirche HJ et al (1993) Environmental control and potential fate of size-fractionated phytoplankton production in the Greenland Sea $\left(75^{\circ} \mathrm{N}\right)$. Mar Ecol Prog Ser 98:297-313

Levinsen H, Nielsen TG (2002) The trophic role of marine pelagic ciliates and heterotrophic dinoflagellates in arctic and temperate coastal ecosystems: a cross-latitude comparison. Limnol Oceanogr 47:427-439

Levinsen H, Nielsen TG, Hansen BW (1999) Plankton community structure and carbon cycling on the western coast of Greenland during the stratified summer situation. II. Heterotrophic dinoflagellates and ciliates. Aquat Microb Ecol 16:217-232

Levinsen H, Turner JT, Nielsen TG et al (2000a) On the trophic coupling between protists and copepods in arctic marine ecosystems. Mar Ecol Prog Ser 204:65-77

Levinsen H, Nielsen TG, Hansen BW (2000b) Annual succession of marine pelagic protozoans in Disko Bay, West Greenland, with emphasis on winter dynamics. Mar Ecol Prog Ser 206:119-134

Li WKW, McLaughlin FA, Lovejoy C et al (2009) Smallest algae thrive as the Arctic Ocean freshens. Science 326:539. doi:10.1126/science. 1179798

Loeng H, Ozhigin V, Ådlandsvik B (1997) Water fluxes through the Barents Sea. ICES J Mar Science 54:310-317

Marie D, Brussaard CPD, Thyrhaug R et al (1999) Enumeration of marine viruses in culture and natural samples by flow cytometry. Appl Environ Microbiol 65:45-52

Mei ZP, Legendre L, Gratton Y et al (2003) Phytoplankton production in the North Water Polynya: size-fractions and carbon fluxes, April-July 1998. Mar Eco Prog Ser 256:13-27

Menden-Deuer S, Lessard EJ (2000) Carbon to volume relationships for dinoflagellates, diatoms and other protist plankton. Limnol Oceanogr 45:569-579

Meon B, Amon RMW (2004) Heterotrophic bacterial activity and fluxes of dissolved free amino acids and glucose in the Arctic rivers $\mathrm{Ob}$, Yenisei and the adjacent Kara Sea. Aquat Microb Ecol 37:121-135

Møller EF, Nielsen TG (2000) Plankton community structure and carbon cycling off the western coast of Greenland, with emphasis on sources of DOM for the bacterial community. Aquat Microb Ecol 22:13-25

Møller EF, Thor P, Nielsen TG (2003) Production of DOC by Calanus finmarchicus, C. glacialis and C. hyperboreus through sloppy feeding and leakage from faecal pellets. Mar Ecol Prog Ser 262:185-191

Müller-Nicklas C, Herndl GJ (1996) Dynamics of bacterioplankton during a phytoplankton bloom in the high Arctic waters of the Franz Joseph Land archipelago. Aquat Microb Biol 11:111-118

Nielsen TG, Hansen B (1995) Plankton community structure and carbon cycling on the western coast of Greenland during and after the 
sedimentation of a diatom bloom. Mar Ecol Prog Ser 125:239257

Nielsen TG, Hansen B (1999) Plankton community structure and carbon cycling on the western coast of Greenland during the stratified summer situation. I. Hydrography, phytoplankton and bacterioplankton. Aquat Microb Ecol 16:205-216

Not F, Massana R, Latasa M et al (2005) Late summer community composition and abundance of photosynthetic picoeukaryotes in Norwegian and Barents Sea. Limnol Oceanogr 50:1677-1686

Parsons TR, Maita Y, Lalli CM (1984) A manual of chemical and biological methods for seawater analysis. Pergamon Press, Oxford

Pasternak A, Arashkevich E, Reigstad M et al (2008) Dividing mesozooplankton into upper and lower size groups: applications to the grazing impact in the Marrginal Ice Zone of the Barents Sea. Deep Sea Res II 55:2245-2256

Piwosz K, Walkusz W, Hapter R et al (2009) Comparison of productivity and phytoplankton in a warm (Kongsfjorden) and a cold (Hornsund) Spitsbergen fjord in mid-summer 2002. Polar Biol 32:549-559. doi:10.1007/s00300-008-0549-2

Porter KG, Feig YS (1980) The use of DAPI for identifying and counting aquatic microflora. Limnol Oceanogr 25:943-948

Putt M, Stoecker D (1989) An experimentally determined carbon: volume ratio for marine "oligotrichous" ciliates from estuarine and coastal waters. Limnol Oceanogr 34:1097-1103

Rat'kova T, Wassmann P (2002) Seasonal variation and spatial distribution of phyto- and protozooplankton in the central Barents Sea. J Mar Syst 38:47-75

Rat'kova T, Wassmann P, Verity PG et al (1999) Abundance and biomass of pico-, nano-, and microplankton on a transect across Nordvestbanken, north Norwegian shelf, in 1994. Sarsia 84:213225

Reigstad M, Wassmann P (2007) Does Phaeocystis spp. contribute significantly to vertical export of biogenic matter? Biogeochemistry $83: 217-234$

Reigstad M, Wassmann P, Wexels Riser C et al (2002) Variations in hydrography, nutrients and chlorophyll $a$ in the marginal ice zone and the central Barents Sea. J Mar Syst 38:9-29

Richardson TL, Jackson GA (2007) Small phytoplankton and carbon export from the surface ocean. Science 315:838-840

Rivkin RB, Legendre L (2001) Biogenic carbon cycling in the upper ocean: effects of microbial respiration. Science 291:2398-2400

Robinson C (2008) Heterotrophic bacterial respiration. In: Kirchman DL (ed) Microbial ecology of the ocean, 2nd edn. Wiley-Blackwell, Hoboken, NJ, pp 299-334

Sanders RW, Porter KG, Bennett SJ et al (1989) Seasonal patterns of bacterivory by flagellates, ciliates, rotifers, and cladocerans in a freshwater planktonic community. Limnol Oceanogr 34:673-687

Sakshaug E, Johnsen G, Volent Z (2009) Light. In: Sakshaug E, Johnsen G, Kovacs K (eds) Ecosystem Barents Sea. Tapir Academic Press, Trondheim, pp 117-138

Schloss IR, Nozais C, Mas S et al (2008) Picophytoplankton and nanophytoplankton abundance and distribution in the southeastern Beaufort Sea (Mackenzie Shelf and Amundsen Gulf) during fall 2002. J Mar Syst 74:978-993

Seuthe L, Rokkan Iversen K, Narcy F (accepted) Seasonal microbial processes in a high-latitude fjord (Kongsfjorden, Svalbard): II. Ciliates and dinoflagellates. Polar Biol

Sherr EB, Rassoulzadegan F, Sherr BF (1989) Bacteriovory by pelagic choreotrichous ciliates in coastal waters of the NW Mediterranean Sea. Mar Ecol Prog Ser 55:235-240

Sherr EB, Sherr BF, Fessenden L (1997) Heterotrophic protists in the central Arctic Ocean. Deep Sea Res II 44:1665-1682

Sherr EB, Sherr BF, Wheeler PA et al (2003) Temporal and spatial variation in stocks of autotrophic and heterotrophic microbes in the upper water column of the central Arctic Ocean. Deep Sea Res I 50:557-571. doi:10.1016/S0967-0637(03)00021-1
Sherr EB, Sherr BF, Hartz AJ (2009) Microzooplankton grazing impact in the western Arctic Ocean. Deep Sea Res II 56:1264-1273. doi:10.1016/j.dsr2.2008.10.036

Simon M, Azam F (1989) Protein content and protein synthesis rates of planktonic ecosystems: a multidisciplinary perspective. Mar Ecol Prog Ser 51:201-213

Sintes E, Stoderegger K, Parada V et al (2010) Seasonal dynamics of dissolved organic matter and microbial activity in the coastal North Sea. Aquat Microb Ecol 60(1):85-95

Smayda TJ (1978) From phytoplankton to biomass. In: Sournia A (ed) Phytoplankton manual, UNESCO monographs on oceanographic methodology No. 6. UNESCO, Paris, pp 273-279

Smith DC, Azam F (1992) A simple, economical method for measuring bacterial protein synthesis rates in seawater using ${ }^{3} \mathrm{H}$-leucine. Mar Microb Food Webs 6:107-114

Sturluson M, Nielsen TG, Wassmann P (2008) Bacterial abundance, biomass and production during spring blooms in the northern Barents Sea. Deep-Sea Res II 55:2186-2198. doi:10.1016/ j.dsr2.2008.05.001

Tang KW (2003) Grazing and colony size development in Phaeocystis globosa (Prymnesiophyceae): the role of a chemical signal. J Plankton Res 25:831-842

Terrado R, Lovejoy C, Massana R et al (2008) Microbial food web responses to light and nutrients beneath the coastal Arctic Ocean sea ice during the winter-spring transition. J Mar Syst 74:964977. doi:10.1016/j.jmarsys.2007.11.001

Thingstad TF, Bellerby RG, Bratbak G et al (2008) Counteractive carbon-to-nutrient coupling in an Arctic pelagic ecosystem. Nature 455:387-390. doi:10.1038/nature07235

Thomas C (1997) Identifying marine phytoplankton. Academic Press, San Diego

Tremblay G, Belzile C, Gosselin M et al (2009) Late summer phytoplankton distribution along a $3500 \mathrm{~km}$ transect in Canadian Arctic waters: strong numerical dominance by picoeukaryotes. Aquat Microb Ecol 54:55-70. doi:10.3354/ame01257

Vaqué D, Guadayol Ò, Peters F et al (2008) Seasonal changes in planktonic bacterivory rates under the ice-covered coastal Arctic Ocean. Limnol Oceanogr 53:2427-2438

Verity PG, Langdon C (1984) Relationships between lorica volume, carbon, nitrogen, and ATP content of tintinnids in Narragansett Bay. J Plankton Res 6:859-868

Verity PG, Wassmann P, Rat'kova T et al (1999) Seasonal patterns in composition and biomass of autotrophic and heterotrophic nanoand microplankton communities on the north Norwegian shelf. Sarsia 84:265-277

Verity PG, Wassmann P, Frischer ME et al (2002) Grazing of phytoplankton by microzooplankton in the Barents Sea during early summer. J Mar Syst 38:109-123

Vernet M, Matrai PA, Andreassen I (1998) Synthesis of particulate and extracellular carbon by phytoplankton at the marginal ice zone in the Barents Sea. J Geophys Res Oceans 103:1023-1037

Vincent W (2002) Cyanobacterial dominance in the polar regions. In: Whitton A, Potts N (eds) The ecology of cyanobacteria, pp 321340. doi:10.1007/0-306-46855-7_12

Wang G, Guo C, Luo W et al (2009) The distribution of picoplankton and nanoplankton in Kongsfjorden, Svalbard during late summer 2006. Pol Biol 32:1233-1238

Wassmann P (2002) Seasonal C-cycling variability in the open and icecovered waters of the Barents Sea: an introduction. J Mar Syst $38: 1-7$

Wassmann P, Rat'kova T, Reigstad M (2005) The contribution of solitary and colonial cells of Phaeocystis pouchetii to spring and summer blooms in the north-eastern North Atlantic. Harmful Algae 4:823-840

Weinbauer MG (2004) Ecology of prokaryotic viruses. FEMS Microbiol Rev 28:127-181. doi:10.1016/j.femsre.2003.08.001 
Wiktor J, Wojciechowska K (2005) Differences in taxonomic composition of summer phytoplankton in two fjords of West Spitsbergen, Svalbard. Pol Polar Res 26:259-268

Willis KJ, Cottier F, Kwasniewski S, Wold A et al (2006) The influence of advection on zooplankton community composition in an Arctic fjord (Kongsfjorden, Svalbard). J Mar Syst 61:39-54
Wilson SE, Steinberg DK (2010) Autotrophic picoplankton in mesozooplankton guts: evidence of aggregate feeding in the mesopelagic zone and export of small phytoplankton. Mar Ecol Prog Ser 412:11-27 